\title{
Rändlind ja Paabeli vang. Omaeluloolisus kahe rahvaluulekoguja saadetistes ${ }^{1}$
}

\author{
Katre Kikas \\ Eesti Kirjandusmuuseumi folkloristika osakonna teadur \\ katreki@folklore.ee
}

\begin{abstract}
Teesid: Artikli keskmes on kahe Jakob Hurda rahvaluulekorrespondendi - Juhan Silbergleichi ja Paulus Paurmanni - omaeluloolised kirjutised. Kuivõrd rahvaluulekogumise aktsioonis osalemine oli üks väheseid tavainimestele avatud võimalusi osaleda kaasaegses avalikus kirjaruumis, pole kuigi ootamatu, et selle raames katsetati väga erinevate kirjutusviiside ning enda kui kirjutaja positsioneerimise võimalustega. Omaeluloolised kirjutised, s.o kirjutised, kus kogujad kõnelevad eksplitsiitselt endast ja oma elust, kuuluvad rahvaluulekogumise kontekstis pigem äärealadele. Samas võib see teema kogutud materjalidesse sugeneda vägagi erinevatel viisidel - on nii selgelt piiritletud elulugusid, materjalide hulka paigutatud üksiknarratiive kui ka kirjadesse sattunud põgusaid vihjeid. Toetudes kahele näitele heidan artiklis pilgu ühelt poolt sellele, kuidas suhestuvad need kirjutised muu tolleaegse kirjakultuuriga - kust on nad leidnud mudeleid endast kirjutamiseks, milliste kirjutusviiside kaudu soovivad nad oma elu mõtestada ja tuleviku lugejale edasi anda. Paulus Paurmanni puhul on peamiseks eeskujuks sentimentaalne kirjandus, Juhan Silbergleichi sulge on aga juhtinud ajakirjanduslik kirjutusstiil. Teisalt huvitab mind ka see, kas ja kuivõrd tulevad nende enesest kõnelevatest tekstidest esile kaasajas olulised märksõnad (nt rahvuslus, mobiilsus, avalikkus), kuivõrd sõltub nende käsitlus valitud tekstindusviisist, ning kuivõrd võime näha sarnasusi/erinevusi.
\end{abstract}

Märksõnad: diasporaa, Juhan Silbergleich, omaeluloolisus, Paulus Paurmann, rahvaluulekogumine, 19. sajand

19. sajandi lõpus Jakob Hurda ja Matthias Johann Eiseni organiseeritud rahvaluulekogumise aktsioonide eesmärk oli panna kirja (s.o kanda üle kestvamasse meediumisse) kõik see, mis senini ringelnud vaid suusõnal ning oli traditsiooni hääbumise tõttu hävimisohus. See tegevus nõudis osalejatelt osavat balansseerimist suuliste ja kirjalike väljendusvormide vastavusse viimisel, ning eriti just vähemharitute puhul võib sageli näha, et keskendutakse eelkõige tegevuse kirjalikule poolele, s.o sellele, et tulemuseks oleks loetav tekst. See asjaolu 
pole kuigi üllatav, kuivõrd eesti keelel puudus ametlik staatus, ning vähegi ametlikumates olukordades pidi kasutama saksa või vene keelt. Nii oli üksnes eestikeelset kirjaoskust valdavatel inimestel võrdlemisi vähe võimalusi ennast kirjutajatena teostada. Samas oli juba piisavalt palju neid, kellele enesemääratlemine kirjutava inimesena, avaliku kirjaruumi aktiivse osalisena, oli oluline ja ihaldusväärne.

Kaheks peamiseks eestikeelset kirjaoskust nõudvaks avalikuks kirjutamisvõimaluseks olid ajalehtedele sõnumite saatmine ja rahvaluulekogumine (vt nt Jansen 2004: 85). Neist esimene oli võrdlemisi piiratud, kuivõrd sõnumid pidid olema lühikesed ja sugugi kõik ei jõudnud trükki; teine aga pakkus võimalust kirjutada piiramatult ning katsetada väga erinevaid žanre ja kirjutusviise. Mitte ilmaasjata pole Mart Laar ühes pidupäevakõnes väitnud, et "rahvaluule kogumine pani kirjutama juba sadu inimesi, luues meist sellega tõelise kirjarahva" (2001: 12-13). Tõsi - nende aktsioonide tulemusel kirja saanud tekstidest pole me üldiselt harjunud mõtlema kui kirjutatud tekstidest, s.o millestki, mis võiks seostuda kirjanduse ja kirjanduskaanoniga. Viimase vaatepunktist jäävad rahvaluulekogujate kirjapanekud kuhugi suulise ja kirjaliku kultuuri vahel asuvale ebamäärasele hallile alale. Seda halli ala võib käsitleda negatiivselt kui mitte-kirjandust või grafomaaniat, kuid mina nõustun pigem antropoloog Karin Barberiga, kes rõhutab, et sellel keskme seisukohalt nähtamatul äärealal toimub pidev uute võimaluste katsetamine - ning isegi kui need uued lähenemised ei mõjuta hilisemaid arenguid, on nad teatud hetkede mõistmiseks siiski olulised, kuna näitavad, mida tolleaegsed inimesed pidasid võimalikuks arenguks (Barber 2006: 385; 2007: 223). Ka on just sellel äärealal näha, kuidas inimesed uut meediumit omaks võtsid ja selle abil oma asendit uues (moderniseeruvas) maailmas mõtestasid.

Üheks põhjuseks, miks neid kirjapanekuid on raske kõrvutada nn päris kirjandusega, on neile omane autoripositsiooni ambivalentsus. Seda ambivalentsust tingib nii kirjapandu seos informandi sõnadega (Ülo Valk on selles kontekstis rääkinud arhiivitekstide kahehäälsusest, vt Valk 2008: 62) kui ka koguja ja organisaatorite vahelise kirjavahetuse käigus toimuv kogutava materjali pidev taas- ja ülemõtestamine, vastastikune piiride kompamine. Selle ambivalentsuse taustal on aga põnev, et kogujad ise rõhutavad oma kirjapandu lehekülgedel väga tugevalt oma kohalolu - mõned lisavad oma nime või initsiaalid pea iga pala lõppu, mõned piirduvad poogna lõpuga, kuid igal juhul võib tunnetada nende soovi rõhutada, et 'isegi kui need sõnad pärinevad kelleltki teiselt, on nad minu kirja pandud'. Ehk siis - nad ise on vägagi teadlikud sellest, et kirjalikus maailmas on oluline olla oma sõnade valdaja/autor.

Teiseks rahvaluulekirjapanekuid nn päris kirjandusest eristavaks jooneks on neile omane seriaalne või lisandustele toetuv printsiip - konkreetse koguja kogu 
kui tervik tekib lühema või pikema aja jooksul järjest lisanduvatest saadetistest, selles kogumis võib olla mitmeid kordusi ja teisendusi, hulgaliselt vasturääkivusi. Barber on selliseid lisanduvale printsiibile toetuvat tekstiloomeprintsiibi tulemuse kirjeldamiseks kasutanud assamblaaži kujundit. Ta rõhutab, et ehkki esmapilgul on selline tekstiloome "vastuolus sügavalt juurdunud modernse ideega kirjandusteosest kui orgaanilisest tervikust", on siiski tegu erinevates kultuurides vägagi levinud nähtusega (2007: 214). Assamblaažidena võib ühelt poolt käsitleda erinevaid koduseid arhiive - inimeste laegastesse, sahtlitesse, kirstudesse kogunenud poolisetekkelisi kirjalike materjalide kogumeid, kus kõrvu juhuleiud, väljalõiked, ametlikud dokumendid, kirjad, omalooming. Erinevates kogukondades võivad selliseid materjalikogumeid sisaldavad mahutid omandada vägagi sümboolse rolli (nt baltisaksa kirjalaekad, vt Jürjo 2011: 298-299, Aafrika plekk-karbid, vt Barber 2007: 176). Teisalt võib assamblaažidena käsitleda ka erinevaid (19. sajandilgi väga populaarseid) albumeid ja salmikuid, milledesse omanikud kirjutavad erinevatest allikatest pärinevaid tarkuseteri, nõuandeid, aga ka oma mõtisklusi jms. Need raamatukesed on küll mõnevõrra ühtsemad kui 'kirjalaekad', kuid ka neid iseloomustab žanriline ja temaatiline mitmekesisus ning selge struktuuri puudumine ja avatud lõpp. Ingliskeelses kultuuriruumis hõlmab selliseid kogumeid üldnimetus 'commonplace book' (vt nt Allan 2010). Eesti uurijad kõnelevad selles tähenduses enamasti salmikutest. Samas rõhutatakse peaaegu alati, et need nimetused on pigem uurijate pandud ja hõlmavad väga eriilmelisi raamatukesi (Kalmre 2010; Allan 2010: 25-35).

Eesti salmikukultuuri uurinud Eda Kalmre kasutab salmikute puhul nimetust (kirjalik või personaalne) arhiiv (Kalmre 2010, 2017), luues nii mu meelest otsese seose nn kirjalaegastega. Valitud mõistega rõhutab Kalmre just raamatukeste sisu mitmeplaanilisust, ta toob näiteks välja, et 19. sajandi talumeeste peetud raamatukesed võisid sisaldada nii erinevaid ajalehtedest tehtud väljakirjutusi, ilmavaatlusi, päevikumärkmeid, saagiandmeid jms (vt Kalmre 2017). Kalmre pakub välja, et selliste 'arhiivide' loomine on omamoodi kompensatsioonimehhanism, püüe "teostada selle tegevuse abil oma täitumata soove, vastamata tundeid, igatsusi ja piiratud vabadust" (2010:216). 19. sajandi kontekstis võib rääkida soovist osaleda üha valdavamaks saavas kirjalikus tekstiruumis - olenevalt isiku reaalsest positsioonist võisid need kogumikud olla nii avaliku meediaruumi pikenduseks kui ka selle asenduseks, oma isiklikest vajadustest lähtuvaks meediaruumiks. Samas peab lisaks kompensatsioonimehhanismile meeles pidama ka assamblaaži tulevikku suunatud, end edasi looma ahvatlevat mõõdet - juba kirjapandu tekitab ideid, mida võiks veel kirja panna, ning küsimusi, millele vastust otsida. Barber nendib et: "tekstivara koondamine entsüklopeediatesse, almanahhidesse, kataloogidesse ja muudesse 
kogumikesse võib osutuda kujutlusvõimet ergutavamaks kui miski muu..." (Barber 2007: 216).

Võimalik, et nii mitmelgi juhul oli hiljem Hurda või Eisenini jõudnud materjal algselt osa just sellisest salmik-arhiivist ${ }^{2}$ - s.o kogujad olid juba eelnevalt tuttavad sedalaadi tekstikogumike loomisega, verbaalsete ühikute kokku kogumisega. Teatavate osiste asetamine rahvaluulekogumise raamistusse muutis nad tunnetuslikult 'avalikumaks' (vt nt Kikas 2017a: 587-588), samas sai nii sageli 'avalikku' ruumi projitseeritud ideid, mis olid erinevatel põhjustel reaalses avalikus ruumis marginaliseeritud (nt moraalselt või poliitiliselt vastuvõetamatud, vt nt Kikas 2014: 320-321). Ka säilis kirjapandu side varasema assamblaažilikkusega - ehk üheks põnevamaks seriaalsust, tulevikku suunatud avatust rõhutavaks võtteks rahvaluulekogujate kirjapanekutes on komme panna kogutu viimasele lehele jätkuvuse lubadus. See võib olla mööndusega 'kui jumal aega ja tervist annab', aga see võib olla ka lakooniline lubadus 'jätkub' saadetise viimasel leheküljel.

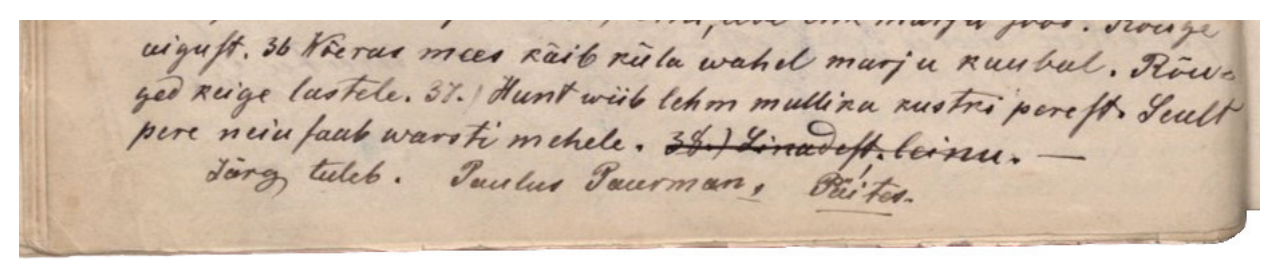

Foto 1. Nagu paljud teisedki kogujad, lubab ka Paulus Paurmann oma esimese saadetise lõpus, et peagi on oodata järge (H II 8, 80). Hurt vastab talle aruandes: "Kui järge selsamal kombel tuleb nagu lahkeste lubate, siis olete kalli päätüki meie esivanemate ajaraamatusse kirjutanud" (Hurt 1889a).

Nii Hurt kui Eisen põimivad neid jätkulubadusi omakorda sagedasti aruannetesse - kas siis otsetsitaadi või parafraasina. Sel kombel kirjadest aruannetesse ja aruannetest kirjadesse liikudes muutub see lubadus osaks rahvaluulekogujate kultuurist ning seob tihedamalt kokku nii ühe koguja omavahelised saadetised kui ka rahvaluulekogujate kogukonna tervikuna. Saadetise lõpus olev lubadus ‘jätkub’ või ‘järgneb’ loob aga seose ka üldisema kaasaegse kirjandusväljaga. Ka 19. sajandi lõpukümnendite ajakirjandus on täis tekste, mil lõpus sarnane märkus, järgedena ilmusid mitte üksnes ilukirjandusteosed, vaid ka pikemad arvamuslood, juhtkirjad või arvustused. Sealjuures oli märkuse ‘järgneb’ viiteväli väga ähmane - järg ei pruukinud tulla järgmises ega ülejärgmises numbris, vaid kunagi, kui selleks ajalehes ruumi oli; polnud kuigi harv, 
et loo lõpp jäigi ilmumata. Ning samasugust lootusrikast tulevikkusuunatust kannavad ka rahvaluulekogujate lubadused - nad ei garanteeri järgnevust, kuid annavad märku sellest, et see võib tulla, et suhtluskanal jääb avatuks.

Üks põhjusi, miks mulle meeldib antud kontekstis assamblaaži-kujund, on see, et see toob esile kogumite mitmežanrilisuse: lisaks erinevatele folkloorižanridele leiame rahvaluulekogujate kirjutiste hulgast ka näiteks (erinevate materjalide) ärakirju, üleskutseid, (palve-, tänu-, soovitus-)kirju, selgitusi, eessõnasid, raamatuarvustusi, luuletusi, sisukordi jpm. Kuid ka mitmehäälsuse - erinevate žanride puhul on koguja enda panus olnud erinev, tema enda isik rohkem või vähem tagaplaanil. Järgnevas liiguksingi ühe konkreetse temaatilise kihistuse juurde neis assamblaažides - omaelulooliste kirjutiste juurde. Ehkki see teema ei kuulunud kindlasti rahvaluulekogumise keskmesse, on erinevad kogujad kogumistöö käigus siiski ka omaenda elust üht-teist kirja pannud - ning teatud mõttes võib öelda, et just sedalaadi kirjutiste kaudu võime näha seda, kuidas need inimesed iseend kaasaegse meediaruumi taustal nägid, millisena nad soovisid endid sinna paigutada.

\section{Omaeluloolisus rahvaluulekogujate kirjutistes}

Niisiis - käesoleva artikli keskmes on rahvaluulekogujate omaeluloolised tekstid. Sellisena on artikkel on jätkuks mu käsitlusele elulugudest, mille rahvaluulekogujad saatsid vastusena Hurda palvele anda informatsiooni koostamisel oleva kogumistöö ajaloo raamatu jaoks (Kikas 2017a). Nüüd sooviksin ühe projekti asemel läheneda teemale isikute kaudu - vaadelda seda, kuidas konkreetsed kogujad omaeluloolist materjali oma saadetistesse põimivad, millistele eeskujudele nad neid luues toetuvad ning mida nad kõige sellega öelda soovivad. On need kirjutised suunatud tuleviku-lugejale mineviku mõistmiseks või soovivad kirjutajad nende abil midagi oma kaasajas muuta?

Omaeluloolise kirjutamise mõiste pärineb kirjandusteadusest, kus sellega hõlmatakse erinevaid tekste, milles kirjutaja viitab endale ja oma kogemusele (Kurvet-Käosaar 2010). Tegu pole žanrimõistega, vaid pigem sooviga varasemalt väga selgelt piiritletud žanride (nt autobiograafia ja päevik) kaudu vaadeldavat valdkonda mitmekesistada, ning näidata, et nende selge identiteediga žanride kõrval on ka teistsuguseid omaeluloolisust kandvaid kirjutusviise (igal žanril on potentsiaal muutuda omaelulooliseks). Antud juhul on eelkõige oluline see, et omaeluloolisus ei pruugi tähendada elu teisendamist üheks konkreetseks alguse ja lõpuga looks, vaid seda, et tulemus võib olla assamblaažilik ajas üha täienev kooslus, kus esineb nii katkestusi, kordusi kui ka vastuolusid. Konkreetsele materjalile lähenedes on mõistet võimalik rakendada üldistavalt, 
lähtudes ideest, et kõik, mida konkreetne inimene kirjutab, on mingi piirini omaelulooline, teisalt on võimalik aga seada keskmesse need tekstid, mida kirjapanija eksplitsiitselt omaeluloolisena esitab. Antud artiklis olen eelkõige valinud teise võimaluse, s.o ma ei küsi niivõrd selle järele, mida on võimalik kirjapandu kui terviku alusel teada saada (või oletada) koguja elu kohta (ehkki päris mööda ei pääse ma ka sellistest tõlgendustest), vaid mind huvitab see, kuidas ja miks konkreetsed inimesed selles raamistuses oma elust kirjutavad.

Viimase mõistmiseks on ühelt poolt vaja meeles pidada kaasaegse omaeluloolise kirjutuse üldist seisu (sellest on väga põneva ülevaate teinud Rutt Hinrikus, vt 2016), teisalt aga ka seda, et tekstid on kirja pandud justnimelt rahvaluulekogumise kontekstis. See, kui palju üks või teine koguja enda elu ja isiku kohta jälgi maha jättis, oli väga erinev. On kogujaid, kelle kohta me ei tea praktiliselt mitte midagi (või teame vaid tänu hilisemate uurijate otsingutele, vt nt Goršič 2017), kui ka neid, kes saadetiste erinevatesse osadesse midagi omaeluloolist kätkevad. Ehkki see, mis põhjusel ja kuidas erinevad kogujad omaeluloolisi katkeid oma saadetistesse põimivad, on äärmiselt varieeruv, tooksin siinkohal näitena esile viis sageli esinevat omaeluloolisuse esinemise konteksti.

1. Kõige levinum (samas omaeluloolise info poolest kõige napim) on omaelulooliste vihjete lisamine kogumistööga liitumise põhjendusele. Näiteks viidatakse sageli kogumistööga seotud info päritolule, viited konkreetsetele ajalehtedele või raamatutele annavad aga ka mõningase pildi sellest, millist meediat konkreetne inimene tarbis (mõnikord lisandub nimetamisele ka viide avaramatele asjaoludele, mis on võimaldanud kogujal ligipääsu neile allikatele, vt nt Wiedemanni lugu H II 37, 532/3). Kuid põhjendus võib sisaldada ka nn negatiivset omaeluloolisust - koguja viitab endale läbi selle, kes ta ei ole. Enamasti on küsimus ebapiisavas hariduses ja kirjutamiskogemuses ning koguja rõhutab, et ta julgeb kogumistööga liituda vaid seetõttu, et kohalikud 'suuremad sulemehed' seda teinud pole. Näiteks kirjutab J. Leppik Saardest: "Pean kül väga kahetsema, et meil siin päris sule mehed näis suikuvad, sest vana vara on kül saada, mis tahab paberisse panna." (H II 22, 1016.) Ning Jaan Raavel: "Teie ülles üidmine, ärratas mind, et ma ommast mustast süllest pidin paar ridda, Teile näha saatma, Meil on palju kes kihelkonna ja Kreiskooli on läbbi teinud, agga pannevad kääd sülle ja puhgavad.” (H I 2, 181.)

2. Pragmaatiline omaeluloolisus. Kogujad esitavad sagedasti Hurdale ja Eisenile erinevaid abipalveid. Enamus neist on seotud sooviga Peterburis või Kroonlinnas tööd leida, kuid on ka huvi edasiõppimise võimaluste 
vastu või soov saada tagasisidet oma loomingule (vt nt Karl Loikeni kirja Eisenile E 431). Enamasti on sellistele palvetele lisatud kirjeldus oma praegusest elukorraldusest, majanduslikust seisust, hariduslikust taustast jms.

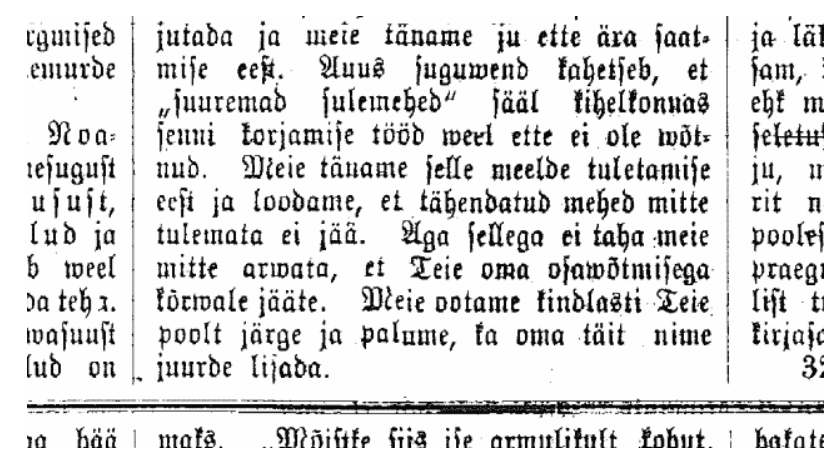

Foto 2. Negatiivse enesepositsioneerimise ohtrus võis osaliselt tuleneda sellest, et mitmed neist kirjakohtadest jõudsid tsitaatidena ka rahvaluulearuannetesse. Siin Hurda vastus Kadrinast pärit J. Neudorvile Hurda neljandas aruandes (Hurt 1888).

3. Vastused Hurda palvele saata enda kohta infot kogumisajaloo raamatu jaoks. Need vastused on nii pikkuse kui ülesehituse poolest väga eriilmelised, enamasti pigem napid ja kirja sisse põimitud, harvem eraldi narratiividena esitatud (lähemalt vt Kikas 2017b). Hurda palvest inspireerituna saatsid mõned kogujad sarnaseid tekste ka Eisenile, põnevaks näiteks on J. A. Weltmann, kes oma viimases saadetises Hurdale lubab elulugu, kuid seejärel otsustab jätkata koostööd vaid Eiseniga ning teeb Eisenile ettepaneku sarnase väljaande koostamiseks (lubadus Hurdale: H II 41, 737, Eisenile tehtud ettepanek: E 6126).

4. Isiklik suhtlus. Kogujate hulgas on inimesi, kes Hurta või Eisenit isiklikult tunnevad ning selliste inimeste kaaskirjad on sageli väga isiklikud. Näiteks Hurda endiste koguduseliikmete kirjad võivad anda väga üksikasjalise ja isikliku ülevaate kohapealsest elust.

5. Omaelulooline aines kogutud materjalide hulgas. Tegu võib olla nii iseseisva narratiiviga ( $n$ t H. A. Schults kirjeldus tema sõjaväesviibimisest on paigutatud kõrvu rahvajuttudega kroonuteenistuse eest ära põgenemisest, H II 67, 451/66) kui ka kelleltki teiselt kuuldud loo kommentaariga (vt nt Jaan Pindi kommentaare saadetises H III 16, 489/508). 
Nagu näha, olen hõlmanud võrdlemisi erinevat liiki kirjapanekuid - on nii pikemaid lugusid kui ka lausejuppe või kujundikasutusi; nii hetkesituatsioonide kirjeldusi kui ka pikemaid ajalõike hõlmavaid kokkuvõtteid. Minu silmis ühendab neid aga see, et nad kõik aitavad ühel konkreetsel inimesel end mingis ajahetkes (ja suhtlussituatsioonis) positsioneerida. Ühe ühendava joonena võib välja tuua selle, et enamik neist on üldjuhul raamistatud enesemadalduslikult, s.o kirjutajad tunnevad vajadust vabandada, et 'härra' aega millegi nii ebaolulisega kulutavad.

Laiemas plaanis on enesemadaldus tavapärane võte, mida nad kasutavad kirjade üldisemas raamistuses, rõhutamaks Hurda kuuluvust sotsiaalses ja hariduslikus mõttes kõrgemale positsioonile. Konkreetselt omaelulooliste kirjapanekute puhul torkab aga silma, et need lõigud saavad sageli veel lisaraamistuse, justkui rõhutamaks, kui sobimatu on enese isikliku elu esiletoomine sellises suhtluskontekstis. Kui abipalvete puhul on selliste hierarhiate rõhutamine ehk isegi oodatav (on ju tegu selgelt alt üles suunatud palvega), siis mõnevõrra ootamatult on sellised raamid juures ka Hurda palve peale kirjapandud elulugudel (vt Kikas 2017a: 592-593) ja isiklikumat laadi kirjadel ${ }^{3}$. Teistest eristub isiklike lugude asetamine kogutud materjali hulka, seal üldjuhul vabandusi pole, samas asetab see kontekst lood nagunii mingile teisele tasandile.

Siiski pole ehk õige neid pidevaid vabandamisi ning enese tahaplaanile surumisi liiga tõsiselt võtta. Vähemalt osaliselt on tegu omamoodi püsivormelitega, millele toetumine andis kirjutajatele tuge ja julgust üldse midagi kirja panna (vrd sellega, et vähemharitud kasutavad ka enam kirjakirjutamisega seotud vormeleid, vt Nordlund 2013: 130-131; Kalkun 2015). Seesugused enesemadalduslikud vormelid võivad olla ühes ja samas tekstis kõrvu vägagi eneseteadlike ja julgete väljaütlemistega. Pikaajaliste korrespondentide puhul on aga näha, et vastastikuste kontaktide rohkenedes muutub sageli tugevalt seegi, kuidas kogujad iseennast oma tekstis positsioneerivad (vrd Josep Freimani kahte elulugu H II 4, 264 ja H II 38, 691/3). Ehkki enesemadaldav raam ei pruugi kunagi täiesti kaduda, võib ta suhtluse edenedes teiste positsioneerumisviiside suhtes marginaliseeruda (vt Helene Maaseni kirjade analüüsi Kikas 2017b) - ning muuseas üsna samamoodi võib aja jooksul muutuda ka see, kui aldis on koguja saadetistesse omaeluloolist materjali lisama.

Lähemaks vaatluseks olen valinud kaks Virumaalt pärit kogujat, kelle saadetiste erinevates osades on võrdlemisi palju omaeluloolisust - Juhan Silbergleichi ja Paulus Paurmanni. Silbergleich ja Paurmann kuluvad võrdlemisi samasse põlvkonda (neil on neljaaastane vanuseerinevus) - see võiks tähendada nende haridustee ja meediakogemuse suhtelist sarnasust. Ka on nende elulugudes 
mõningaid ühiseid momente (näiteks diasporaakogemus). Samas on see, kuidas nad saadetistesse omaeluloolisi tekste põimivad, võrdlemisi erinev, nagu on erinev ka see, millistele avalikust kirjaruumist lähtuvatele eeskujudele nad toetuvad. Paurmanni teksti analüüsisin põgusalt ka oma varasemas kogujate elulugude artiklis (Kikas 2017a), kuivõrd Silbergleichi omaeluloolisuse lähted on mõnevõrra teised, siis eelmainitud artikli valimisse tema kirjutatu ei jõudnud.

\section{Juhan Silbergleich (1854-1927): Eestlane kannatab igal pool ...}

Juhan Silbergleich sündis 1854. aastal Simuna kihelkonnas, Salla vallas taluperemehe pojana. Tema haridusteest pole midagi teada, kuid asjaolu, et ta tegutses kohaliku vallakirjutajana, võiks viidata, et ta oli vähemalt kihelkonnakooli läbinud. Tema suhted kohaliku mõisnikuga olid võrdlemisi pingelised ning päädisid mitme kohtukäiguga; samuti nõustas ta teisi kohalikke mõisnike-vastases tegevuses ning kirjutas erinevatesse instantsidesse kaebe- ja palvekirju. Pärast seda kui mõisnik tema kaebuse tagajärjel 1882. aastal 300 rubla trahvi sai, muutusid suhted nii keeruliseks, et 1885 . aastal võttis ta mõnede kaaslastega vastu otsuse välja rännata. Sihtkohaks oli Jamburgi maakond (Peterburi kubermang), kus nad ostsid Zagoritsõ mõisa, tehing ei olnud kuigi edukas, ja ajal, mil ta liitus rahvaluulekogumisega, oli aastaid kestnud kohtuvaidlus veel pooleli (H II 33, 224). Siiski paistab silma, et oma kirjale kirjutab ta alla "Sagoritsa mõisas maa omanik Juhan Silbergleich" (samas).

Silbergleichi osalus Hurda rahvaluulekogumise aktsioonis oli lühiajaline kolme kuu jooksul (1888. lõpp, 1889. algus) saatis ta Hurdale kaks saadetist (neist esimese pseudonüümi "Eestipoeg" all). Kirjapandud materjal pärineb tema enda mälestustest ning kogumistöö ajend oli tal sarnane paljude teiste diasporaakogujatega (vrd nt Peterburis elava Haapsalust pärit J. Neudorvi kirja H II 33, 179/80) - avastus, et tema kodukihelkonnas kohapealseid kogujaid ei ole: "et seekoht paberi peal valgeks ei jäeks, võtsin amugi roostetand sule, ja tuletan vanemate jutusi meele!" (H II 33, 185). Esimese saadetise kaaskirjast tuleb aga välja, et ta on rahvaluule vastu huvi tundnud ka varem, nimelt on ta saatnud "kauni kogu orja-põlve riismeid dr Veskele" (samas). Seega on võimalik, et Hurdale saadetud materjalid on mälestus sellest, mille ta varasemalt on juba läbi kirjutanud (kuna Veske Virumaa materjalid on kaduma läinud, siis võrrelda pole võimalik, vt Saukas 2004: 175).

Silbergleichi omaeluloolised tekstid võib laias laastus jagada kolmeks: mõlema saadetise kaaskirjad (H II 33, 185, 224), teise saadetise mõnevõrra 
pidulikum eessõna (H II 33, 209) ning mõningate omaelulooliste nüanssidega kultuurilooline kirjutis (H II 33, 210/7). Kõige eluloolaadsem on teise korjanduse kaaskirjas olev lühiülevaade, mille Silbergleich juhatab sisse üsna tüüpilise enesemadaldusliku raamiga: "Ärge pange pahaks, kiri on vaevane ja korjandus kõhn, lisan paar rida oma rõhuvast elukorrast” (H II 33, 224). ${ }^{4}$

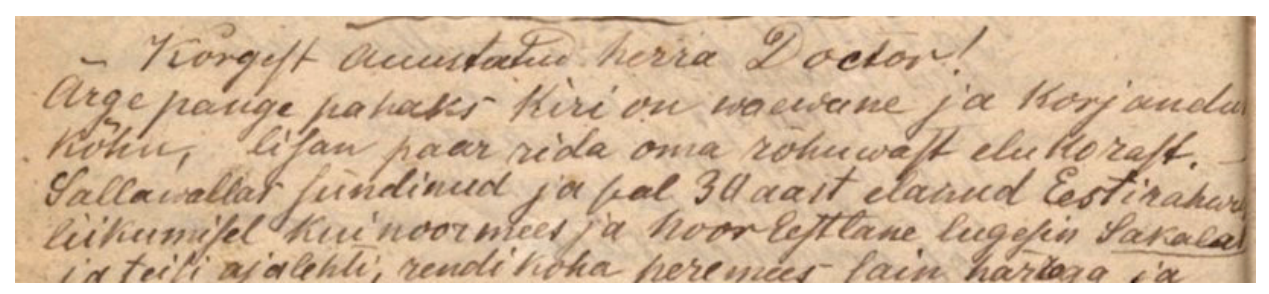

Foto 3. Juhan Silbergleichi eluloo lühiülevaatele eelneb võrdlemisi tavapärane vabandus (H II 33, 224).

Teise korjanduse eessõna on stiililt võrdlemisi kirjalaadne, kuid selle alguses puudub otsene pöördumine Hurda poole, ka on just selles tekstis kõige enam esil Silbergleichile omane kogukonna eest kõnelemine (vt allpool).

Kirjades ja teise korjanduse eessõnas oleva eluloolise ainese raamistuses tõuseb eile kolm aspekti. Esiteks rõhutab Silbergleich, et tema huvi rahvuslike ühisettevõtmiste vastu on olnud pikaajaline. Nii viitab ta päris esimese kirja alguses oma suhetele teiste kirjameestega: "mina kui puudulik kirjamees, olin omal kallil sündimise maal kirjameestega tutav ja mõistust ning jõudu mööda kaas-tööline, saatsin kauni kogu orja-põlve riismeid Dr. Veskele“ (H II 33, 185). Teises saadetises aga märgib: "Eesti rahva liikumisel kui noor mees ja noor Eestlane lugesin Sakalat ja teisi ajalehti” (H II 33, 224)5. Seega: kogumistööga liitumine oli tema jaoks võimalus jätkata osalemist rahvuslikus liikumises ka pärast väljarändamist.

Teiseks rõhutab ta enda väljarändaja staatust. See tähendab ühelt poolt eraldatust kodumaast ning rahvuskaaslastest. Viimast on ta eriti kujundlikult esitanud teise korjanduse eessõnas:

Üht haledat rõ̃mu tundmist teeb meile kallilt kodumaalt ära lahkunud ja võera venemaa kubermangudesse elama asunud väljarändanud Eesti üksiku perekondadele! Kõik ühised isamaalised tööd mis suguvenad ja õed kodumaal üheskoos ja ühel nõul korda saatvad, nagu elavalt vana vara korjamine, rõomustab ja anab troosti kui ajalehest neid sõnumeid loeme, aga ise kui Israeli lapsed Pabeli vangis oma kandled [---] külge panud ja 
nutu laulusi Kali kodumaa suguvendade peale mõeldes laulame. Kui ära põlatud välja tõugatud liikmed, suurem hulk raskeid elurõhumisi mis kodu isamajas aimata ei võinud siin alalise ja mitmesuguse pigistamise all kannatada saab! (H II 33, 209)

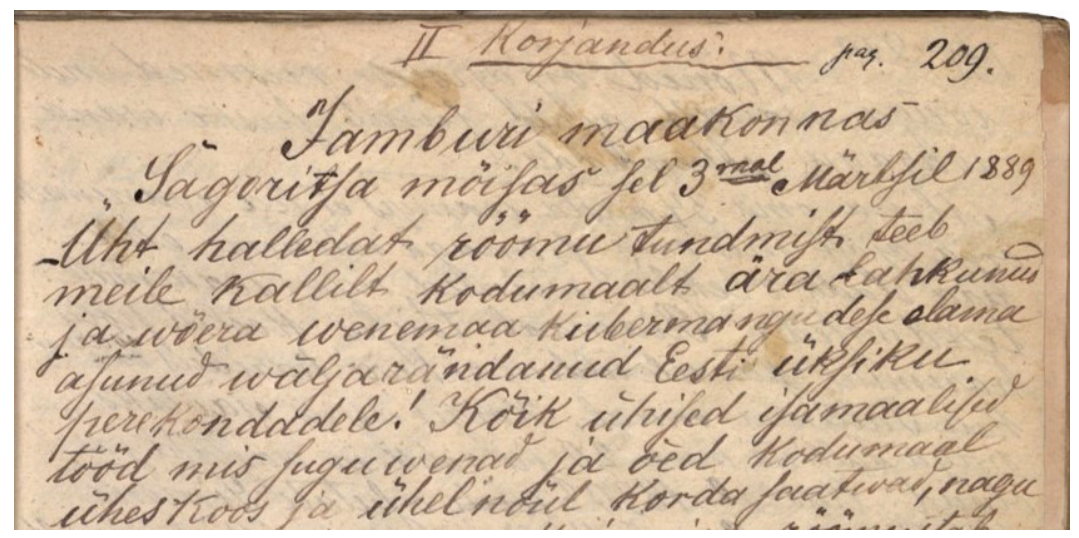

Foto 4. Juhan Silbergleichi teise korjanduse alguses oleva eessõna algus, kus tuleb eriti selgelt esile tema komme kõneleda diasporaakogukonna nimel (H II 33, 209).

Ka rõhutab ta, et väljarändamine on olnud sunnitud valik, välja rändavad inimesed, kellel kodumaal lootust maale pole: “..aga süda rõhub rindas, et suurem hulk ka mite kerges meeles, vaid sunitud on välja ränata, maa omanduse püidmises, ka kodumaal on mõisa muld, kalim veel kui kuld.” (H II 33, 209.) See väljarändamise kui sunnitud valiku rõhutamine on tõenäoliselt vastuseks kaasaegses ajakirjanduses levinud halvakspanule väljarändajate aadressil (Jürgenson 2015: 32).

Kolmanda aspektina tõuseb aga esile omaenda negatiivse elukogemuse üldistamine kogukonna tasandile. See avaldub näiteks ülalgi näha olnud kombes kirjutada mitte enda, vaid mingi rühma vaatepunktist ('kodumaalt ära lahkunud ja võera venemaa kubermangudesse elama asunud väljarändanud Eesti üksikud perekonnad'). Kuid kirjades on ka veelgi üldisemale (rahvuse tasandile) viitavaid hüüatusi. Teise saadetise eessõna lõpetab näiteks nending: "Rasked ajad on sul praegu õnetu Eestirahvas!" (H II 33, 209); esimese saadetise kaaskirjas on aga märkus: "Peab ütlema: Eestlane kannatab igal pool!" (H II 33, 185). See kogukonna eest kõnelemine kõlab hästi kokku tema viitega, et varasemalt aitas ta teistel kogukonnaliikmetel kaebe-, palve-jms kirju kirjutada, s.t et tal on oma kogukonnas tõepoolest olnud juhtiv positsioon. Teisalt ei tea 
me kahjuks seda, milline oli tema osa väljarännu ja mõisaostmise plaanides kas oli ebaõnne üldistamine kogu eesti rahvale soov kompenseerida tunnet, et ta on teisi alt vedanud? Aga selline üldistav kõneviis võis olla tingitud ka tundest, et just nii kõlbab endast sotsiaalses hierarhias kõrgemal positsioonil seisvale Hurdale oma isiklikust ebaõnnest kõneleda.

Nende üldistavate ohetega kajab aga kokku üks hoopis teise žanri kuuluv ning korjanduse põhiossa paigutatud kirjutis "Mõned orjapõlve riismed mite väga vanast ajast, sünib siiski vana varaga ühendada" (H II 33, 210/7), mis on pühendatud mälestustele pärisorjuse ajast. Tekst algab mina-vormis märkusega, et nooruse tõttu tal isiklikke mälestusi sellest ajast ei ole: "Mina oma 34 aasta vanuses ei tea vanemast orja ajast mis ma oma silmaga näinud ehk ära elada oleksin võinud, aga vanemate teadmised.” (H II 33, 210.) Seejärel viitab ta põgusalt kohalikule kooliajaloole - peamiselt selleks, et rõhutada, kui mahajäänud Tallinna maa haridusolud veel mitukümmend aastat tagasi olid. Selle juurest liigub ta aga kirjutise peateema - mõisnike ja talurahva suhted juurde. Nii viitab ta, et aeg oli 'must ja pime' ning võrdleb eestlaste olukorda Ameerika suhkruistandustes töötanud orjade omaga:

Veel sel ajal ja tagasi poole selest vaadata oli must ja pime aeg kellest meie vanemad väga hästi teavad rääkida, 10-12 aastased poisikesed käisid mõisa korral ja vaimuks loomi söötmas ja kõik tööd mis peale pandi tegemas, tugevamad neist olid oma tervise ja ramuga raske viinaköögi töös, mis pärast hobuse ja nüüd auru jõul tehase, aga siis meie Eestiorjad nagu Amerika istanduse peremehed oma rahva orjad Sukru pilliroos ja sukru veskites peavad. (H II 33, 210)

Sissejuhatusele järgnevad erinevad näited mõisnike omavolist talupoegade üle. Hulgas on ka mitmed kohtukäigujuhtumid, mis näitavad, et talumehel polnud mingit lootust kohtus mõisniku vastu õigust saada - võimalik, et omaenda kohtukäimise tõttu oli Silbergleich sellele teemale eriliselt avatud. Kuid on ka üldisemaid vägivalla ja liikumisvabaduse piiramise lugusid (lood on seotud konkreetsete mõisnikega, kuid motiivid on enamasti väga levinud, nt orjade vahetamine koerte vastu (H II 33, 211).

Ehkki ta rõhutab teksti alguses, et ta on liiga noor, et ise pärisorjuse aega mäletada, on teksti põimitud siiski ka üks isiklik mälestus kohtumisest mõisnikuga:

Mina olin püksata 7aastane laps kui mõisa herra kiltriga õue tuli, isal oli kodusõniku vedu päev isa oli väljal, kutsus minu kadunud õnsa ema ete, kel veikene laps sülles, küsis miks vaimu tüdruk mõisas ei ole, ja lõi oma käega 2 kord emale mööda palet, niisama teinud naabri perenaesega, kelel ehmatusest roos rinda lõi. (H II 33, 213) 
Kirjutise lõpuosas liigub ta kaasajale lähemale, ning toob välja erinevaid pärisorjuse kaotamise järgse aja probleeme. Neist mõne osas jääb ta neutraalsemale positsioonile (liikumisvabadusega kaasnev kaugelt kaasade toomine), mõne osas on aga väga kriitiline. Viimaste hulka kuulub näiteks see, et maata inimesed sattusid varasemalt tunduvalt kehvemasse seisu - seisu, kus ainsaks väljapääsuks oli väljarändamine. See arutlus kõlab otsapidi kokku Silbergleichi enda diasporaa-kogemusega, samas on tema väljarändamise põhjused ju mõnevõrra teised (tema ei ole maata-rahva järeltulija).

See kirjutis on žanriliselt ambivalentne. Juba pealkirja teine pool “... sünib siiski vana varaga ühendada" näitab, et Silbergleich pole päris kindel, kas sellised tähelepanekud ikkagi kuuluvad vanavara hulka; teksti lõpetab ta aga märkusega "Keerame nüüd natuke vanavara poole, eelpool jut oleks nagu ajalehele kirjutud!" (H II 33, 217) (järgneb pulmade kirjeldus). Viide ajalehele on mitmes mõttes kõnekas, kuivõrd teksti sees märgib ta kommentaariks mõisnike vägivallategudega seotud lugudele: "Kõik need hirmsad teud ei lase Sehsur läbi trükkimiseks.” (H II 33, 212.) Ehk siis: tekst on küll nagu ajalehele kirjutatud, kuid tegelikult pole lootust, et ta kunagi trükivalgust näeks. Ehk siis - sarnaselt nii mõnelegi teisele kogujale, käsitles ka Silbergleich kogumistööd kui omamoodi avalikkuse laiendust, kui võimalust panna kirja ja 'avalikustada' kõik see, mida ei suudeta päris avalikku sõnasse viia. Võimalik, et mingi osa sellest Hurdale saadetud tekstist baseerub mõne(de)l reaalselt ajalehest tagasilükatud kirjutisel (sama kahtlus tekib ka muistset valitsemiskorda analüüsivat kirjutist "Vanad Eestlased ja nende elu" lugedes, H II 33, 205/7).

Samas ei pruugi see seos olla siiski nii otsene, kuivõrd ainus teadaolevalt ajalehes avaldamiseks kirjutatud Silbergleichi tekst kannab hoopis teistsugust sõnumit. Nimelt on ta 1878. aastal saatnud pikema kirja Sakalale. Kirja esimene pool, mis kiitis tolle aasta viljasaaki Virumaal, ka tõepoolest ajalehes ilmus (Silbergleich 1878), teine - tunduvalt mahukam osa -, mis käsitles kohaliku elu-olu paranemist viimastel aastatel, jäi ilmumata. Mis on selle teksti juures põnev, on aga see, et elu-olu paranemise eest annab Silbergleich au kohalikule mõisnikule: “... Muud uema aja edendused meie nukas, mis meie auväärt ja armolik Salla mõisa peris Herra A. V. Harpe oma praeguse 3dema aasta hoolsa truvi ja tundliko mõistusega Hakenrihti koho ametis on jõudnuvad korrale seada..." (EKLA f 47, m 40: 24, 1 1/1). Me ei tea täpselt, millal Silbergleichil kohaliku mõisnikuga probleemid tekkisid (kunagi enne 1882. aastat), ometi on väga raske oletada, kas see ülistav stiil lähtub reaalsetest headest suhetest või teadlikkusest selle osas, kuidas tuleb ajalehele kirjutades võimulolijaid kujutada. 
Silbergleichi kirjapanekute omaeluloolise kihi moodustavad kirjad ning arvamusartikli ja kultuuriloolise ülevaate piirimaile jäävad tekstid. Johtuvalt kaastööde lühiajalisusest ja vähesest mahust (kaks saadetist kolme kuu jooksul), paistabki silma omaeluloolise ainese suhteline rohkus teksti üldhulgas. Samas puuduvad tema kirjades ja saadetistes kogumistöö jätkuvusele (kontakti hoidmisele) suunatud kirjakohad. Kuivõrd oma esimese saadetise saatis ta varjunime all (päris saadetise lõpus on ühes kohas ka siiski ta oma nimi), teise aga oma pärisnime all, siis Hurda aruannetes on tema saadetised arvele võetud erinevate inimeste saadetutena (s.o mõlemad paiknevad saadetise selles osas, kus antakse tagasisidet esmakordselt saatnutele, vt Hurt 1889b ja Hurt 1889c). Köites on need kaks saadetist kõrvuti pandud, seega mingil hetkel Hurt saatja samasuse siiski avastas. Siinkohal on aga oluline just see, et ehkki Silbergleichi kaks saadetist saabusid väga väikese ajavahega, on nad ikkagi kuidagi teineteisest eraldi, katkendlikud.

Miks Silbergleichi kogumistöö katkes? Nagu enamiku kogujate puhul, võib siingi välja tuua vaid oletusi. Kõige lihtsam oleks pakkuda, et eluraskustest johtuvalt tal lihtsalt polnud enam aega jätkata. Kuid on võimalik ka vastupidine seletus - probleemid lahenesid, ning põhjust eestlaste raske elusaatuse üle kurta enam polnud. Viitasin ennist, et tulenevalt mõnedest ajakirjanduslikuna näivatest žanrivalikutest Silbergleichi saadetistes on põhjust oletada, et lisaks eksplitsiitselt väljendatud soovile oma kodukihelkonna mainet päästa kannustas Silbergleichi koguma ka lootus selle aktsiooni kaudu oma diasporaakogukonna mured avalikuma auditooriumi ette tuua. Samas on võimalik, et probleemi kadumise asemel leidis Silbergleich mingi muu (tema eesmärkidele enam sobiva) kanali - seega võime rääkida ehk sellest, et ta pettus rahvaluulekogumise kui avaliku kanali mõjujõus.

\section{Paulus Paurmann (1850-1903): olen mitmes läätse leemes keenud...}

Paulus Paurmann sündis 1850. aastal Jõhvi kihelkonnas väga heal järjel talupidaja pojana. Kui ta oli 12aastane, hävis kogu perekonna vara tulekahjus. Hoolimata perekonna vaesusest õnnestus tal mingil määral õppida Jõhvi kihelkonnakoolis. Paurmann pidas elu jooksul mitmeid ameteid: vallakooli õpetaja, mõisavalitseja, metsavaht, põllumees. Rahvaluulekogumisega liitumise ajal elas ta omamoodi kaksikelu - suviti pidas vennaga kahasse Päite vallas talu, talviti õpetas Peterburi kubermangus Lilienbachi (Novo-Ivanovskaja; Paurmann ise kirjutab mõisa nime Lillenbach) mõisas asunikeküla koolis.

Hurda kogumisaktsiooniga liitus ta 1889. aastal ning saatis aastatel 1889 1893 rahvaluulet üheksal korral. Hurda aruandevastused tema saadetistele 
on alati keskmisest pikemad ja kiitvad - erilist äramärkimist leiab alati murdekeele kasutus (vt nt Hurt 1890, sama tõstab esile ka Korb 2017: 13).

Tema kirjutiste omaelulooline kiht jaguneb laias laastus kaheks: kaks selgelt eluloolist kirjutist: "Paulus Paurmani elu lugu" (H II 37, 201/32) ja seda täiendav kogumislugu "Vana vara korjandusest" (H II 37, 233/239) ning mõned kogutud materjalidesse põimitud minavormis lõigud. Paurmanni saadetiste kaaskirjad on pigem napid, ning omaeluloolist on neis väga vähe. Erandiks on kiri 1889. aasta 5. detsembrist (EKLA f 43, m 17: 17, 1 1/1-1/2), mis viitamata ühelegi konkreetsele eluloolisele sündmusele, annab kujunditele toetudes eluloo lühikokkuvõtte (lõik on tegelikult põhjenduseks, miks tal pole võimalik Hurdale oma fotot saata):

Ma tunnen kül selgest ära, et minu kord ja kohus oleks ka teile oma päeva pilt saata; aga! Peen vabandama öeldes: elo saatus on mind ästi sakrinud, vaivad vajotand ja piina piigistand, nõnda et kõige oolsa töö ja kokku hoidmise läbi, aasta otsas rehnungi otsadel ike varma vaaks vahet on jäänd.

Et ma kül mitmes läätse leemes olen keenud: siiski! Jumal tänatud on mo liha ja luud naha sees veel kõik terved. Praigu on aga pikse pilved ja rahe raginad minust mööda jõundud ja ma näen nü̈̈d jälle joo päikse lahket valgust oma saatuse teel. (EKLA f 43, m 17: 17, 1 1/1)

Samas kirjas annab ta ka lubaduse kunagi tulevikus oma elulugu kirja panna:

Kui ma enam vana vara ei leia, siit kitsast maa ja metsa vahel seisvast kive kildulisest maast; siis on mul nõu oma elu lugu teile kirjutada. Ehk kõlbab mõnel inimesel ka aja viiteks kord üle silmitseda. (EKLA f 43, m 17: $\left.17,1 \frac{1}{2}\right)$

Eluloo saadab ta Hurdale kaks aastat hiljem, 1891. aastal. Ehkki Paurmann ei viita ei selles kirjas ega eluloo enda juures Hurda soovile kogujatelt elulugusid saada, võib eeldada, et ta oli Hurda palvetega tuttav, teadaolevalt jälgis ta Hurda aruandeid juba alates 1888. aastast (ehk siis enne seda, kui ta kogumistööga liitus, vt H II 37, 235).

Paurmanni elulugu on kõige mahukam vastus Hurda järelepärimisele (koos kogumislooga peaaegu 40 lehekülge), ka eristab teda teistest selgem sisemine struktuur ning terviklikkuse taotlus. Lugu on jaotatud kolmeks peatükiks, milledest esimene - "Lapsepõlv" - kirjeldab elu rikkaima talu lapsena. Teine peatükk "Õnnetus" kirjeldab elu pärast seda, kui ootamatu tulekahju kogu vara hävitas, see peatükk hõlmab suurema osa tekstist, justkui rõhutades, et veel aastakümneid hiljem on just see tulekahju see, mis ikka veel tema elukäiku mõjutab. Samas see peatükk siiski pole läbini mustades toonides. Näiteks viitab ta oma pulmadele kui lõbusale sündmusele: "Varsti said kihlused peedud 


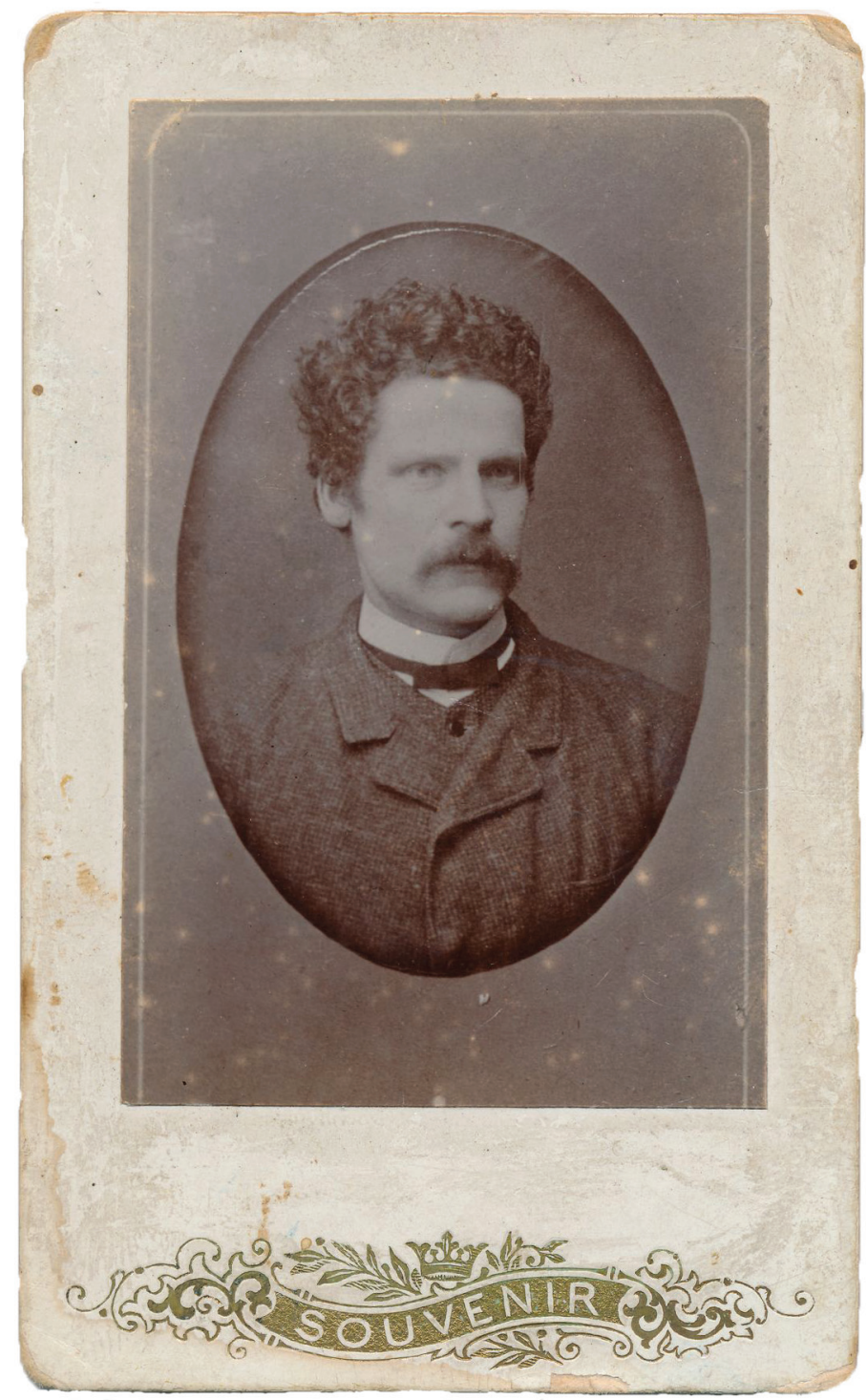

Foto 5. Paulus Paurmann. ERA, Foto 5102.

ja 1873. 25. März. Laulatud, ka hästi rõõmsad pulmad peetud." (H II 33, 217) Eluloo kolmanda peatüki pealkirjaks on aastaarv - 1887 - just sel aastal sai Paurmann tööd Lilienbachi mõisa koolis - sündmus, mida ta käsitleb positiivse pöördepunktina oma elus. See valik on tegelikult väga märgiline, kuivõrd nagu viidatud sisaldas ka eelmine peatükk viiteid positiivsetele elusündmustele. 


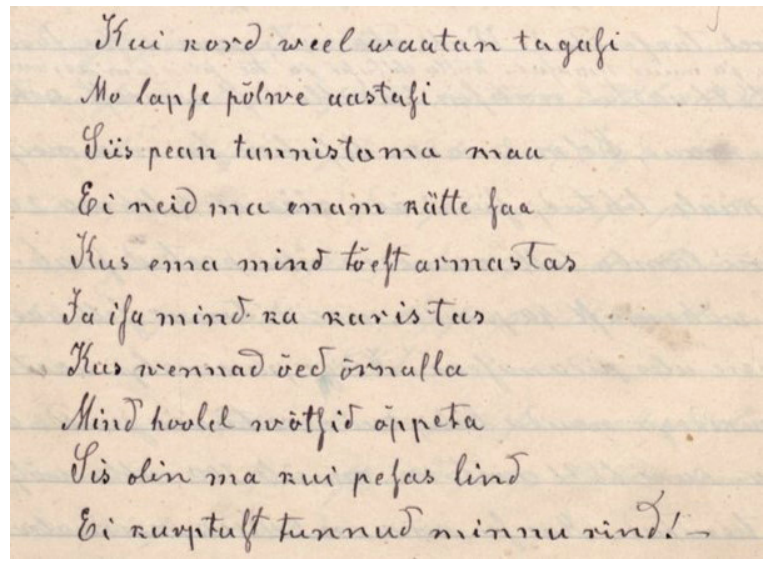

Foto 6. Paulus Paurmann kasutas oma eluloo esitamiseks mitmeid erinevaid žanre. Siin luuletus, millega ta lõpetas oma eluloo (H II 37, 232).

Samas oli Lilienbachi koolis töö leidmine miski, mille mõju oli tuntav veel ka eluloo kirjutamise hetkel - ilmselt just sellele hetkele viitas ka 1889. aasta kirjas olnud kujund 'pikse pilvede ja rahe raginate möödumisest' (EKLA f 43, m 17: 17, 1 1/1).

Oma eluloo lõppu on ta aga paigutanud õnnelikule lapsepõlvele (ja selle kättesaamatusele) tagasiviitava luuletuse - luues sel moel otsese seose alguse ja lõpu vahel.

Tõsi - luuletus pole veel päris lõpp, sellele järgneb omakorda kokkuvõttev lause, mis rõhutab eelnenu valikulisust ning elu lõpetamatust: "Ninda tänini minu elo saatus. Kartsin et liig pitkaks venib selle pärast õlen mõndati vähemat käänakut maha jätnud.” Millele järgneb veel eriti detailne aja ja ruumi määratlus: "Vene maal, Lillenbachis, 11dal Detsembril 1891. õhtul kell 11," (H II 37, 232).

Eluloole järgneb lühem tekst "Vana vara korjandusest", mis aga ei käsitle üksnes vanavarakogumist, vaid vaimsete huvide arengut üldisemalt. Kirjutist alustab ta viitega sellele, et oma lõbuks hakkas ta rahvaluulelist materjali kirja panema juba 1875. aastal, kuid oli sunnitud selle lõpetama elukorralduse muutuse tõttu. Samas rõhutab ta, et pikkade tööpäevade tõttu pidi ta loobuma mitte üksnes rahvaluule kogumisest, vaid ka igasugusest lugemisest (H II 37, 234). Pöördepunktina toob ta ka selles kirjutises esile Lilienbachi koolis tööleasumise - just siis tekkis tal aega lugeda, ning lugemise kaudu jõudis ta jälle ka rahvaluule üleskirjutamiseni.

Ühe teda eriliselt huvitanud tekstiliigina toob ta välja lood lihtsate inimeste elust: 
Kõige enam tröösti sain neist raamatutest, mis suurel mõodul, teiste inimiste vaivalisi ja ädälisi elu saatusi mulle ette kujutasid; ja muidugi minu omadest kaugelt ja kõrgelt üle käisivad. (H II 37, 235)

See viide annab väga selge viite eeskujudele, mida ta omaenda elulugu luues silmas pidas. Sentimentalistlike tekstide mõjule viitavad näiteks eriti kurbades kohtades olevad looduskirjeldused, sündmuste kirjelduste vaheldumine oma tunnete kirjeldustega ning viited jumala armule, samuti rohke hüüumärkide ning ekspressiivsete hüüatuste kasutamine. Järgnevas näites on kõik mainitu kenasti näha:

Metsa vilus üksi käies, käisin mõttes oma elo saatuse kõik läbi, lapse põlvest kuni tänine. - Ka mõtte läks viimaks tuleviku pääle. Süda lei kurvaks ja pisarad tulid ulgana palgele. Ma õlin joo kõik sellega nüüd kautanud, kohast lahti, kraam laiali pillatud, ka au vällä riisitud, ma ôilin lahti lastud! ja oma endiste vaindlastele naeruks saanud! Oh! küll ôli see raske! - ei ma õska siin seda südame valu seletada, kudagi moodi ei oleks tahand ma oma kurba abikaasat mitte nähä. Tema ja laste kurvastus vaivaski mind veel enam.

Ma tuntsin: et ôlin ära põlatud kõigist maha jäötud ei mull õld usaldust ega lootust see kord enam sugulaste ega sõpradegi pääle.-

Kui nii tundsin, üksinda olema, palusin silma veega ja rõhutud südamega Jumalat, et tema mind võttaks edaspidi jälle oma armu hoole alla. Sai palve lõppetud, mo süda sai rahulisem, ja silma pisarad ei voolanud enam, kuni rõõmsa südamega ruttasin kodu poole. Veike poeg jookseb rõõmuga vasta, ja ütleb: "Meie saame oma vankri kätte, üks mees tõi meile selle üle teadust. Ja ajajad saksad kinkisid meile 5 rubla raha.-

Nüüd korraga lapse rõõmust meelt nähes läks ka minu süda rõõmsast, ma tundsin: Mina ei õle joo siis sugugi veel maha jäätud, kui veel mõnigi inimene minu ädas kaas tundlik on.

Ma tänasin Jumalat, kes inimeste südamed minu vasta armuliseks tegi. (H II 33, 226/7.)

Veel üheks oluliseks poeetiliseks võtteks, mille kaudu ta eluloosündmusi (nii ette- kui tahaulatuvalt) kommenteerib, on vanasõnad. Kooskõlas sellega, et suurem osa loost on paigutatud peatükki nimega "Õnnetus", on ka enamik vanasõnu seotud selle teemaga:

Vana sõna ütleb: õnnetus ei üia tulles vaid oigab mennes. (H II 33, 206)

Aga! õnnetused ei käi metsa puude mööda vaid ikka ja ikka inimeste möödä! (H II 33, 212)

Sest kes paremat otsib, see sagedast pahemat leiab. (H II 33, 219) 
Nagu öeldud, on lisaks neile kahele selgelt omaeluloolisele kirjutisele ühtteist samalaadset ka kogutud materjalide hulgas. Elulooga samas saadetises on kirjutis "Une nägudest" (H II 46, 188/6), mis koondab erinevate inimeste unenägusid. Kolmanda punktina on esitatud üks tema oma - unenägu, mida ta nägi vahetult enne Lilienbachi kooli töö leidmist (H II 46, 191/2).

...Ühel ööse nään mina unes: Mina seisän Jõvi keriku ligidäl ukse kõhal, vahtra puude all, poolotra leibä kaindla all. Üks nägemata ääl ütleb sääl mulle: "See leib, midä so kaindlas on ei õle sinu leib." Selle järel kados see pool leibä mul kandlaust vällä. Mina läksin keriku kõrva alja roho platsi pääle, kus vahtrad ja saare puud paiga ilustuseks on istutud. Sääl ôli palju müttamulla unnikuid. Mina lükkän ühe neist salaga laiali ja mulla uniku seest tuli ilus puhtast rukki jahudest tehtud leib lagedale. See sama endine nägemata hääl ütles: "Vott see on siin sinu leib; võtta ta omale." Mina võtsin.-

Varsti perast seda sain kuulda: Lillenbachi mõisas on koolmeistri kõht saada... (H II 37, 191/2)

Unenäo kirjeldusele eelneb olukorra kirjeldus, mis suuresti kordab eluloos esitatut, samas uue töö leidmisega seonduv (mis järgneb unenäole), on detailsem kui eluloos. Ehkki unenägu on esitatud selle konkreetse eluloosündmuse kontekstis, jääb ta unenäo ja reaalsuse seose osas mõnevõrra kahtlevale positsioonile: "Mene sa tea, kas see unenägo seda siis tähendaski, et Jõvist tunnistuse sain sellega kõha sain ja sellega oma perele üles pidamise abi võisin teenida." (H II 37, 192). Üldisemas plaanis on aga põnev, et unenägu seostub just sellesama sündmusega, mida ta ka kahes eluloolises tekstis pöördepunktina esitas.

Teine omaelulooline lõik sisaldub aasta peale eluloo saatmist valminud saadetises. Kirjutise “Tagasi vaate vana aiga" (H II 46, 65/71) eesmärgiks on tõestada, et vanasti ei olnud inimeste elu (ning inimeste ja mõisnike suhe) ainult negatiivne:

Ninda kuida kulla õlen saand vanade suust, õlid vanal peris orjuse ja ka teo orjuse ajal suurem jagu mõisnikuid ilma alastuseta oma alamate vasta; aga ka nii ja nii mitmed on neist ôlled, kellel inimlikud tundmised põuves on põksund. - Naad on mõistlikult oma töö rahvaga ümber käind.-

Suure rõõmuga ja üva meelega kirjutan ma ninda palju kui kulla õlen saand ka vana aja üvädusest ja lahkusest. (H II 46, 65/6)

Tekst sisaldab lugusid inimesi mõistnud ja aidanud mõisnikest, aga ka üldisi kultuuriloolisi märkusi (kohalikud haridusolud, esimesed korstnad jms asjad külas). Endale viitab ta seoses Päite vallakooli ajalooga, kuivõrd ta ise oli selle kooli õpetajaks aastatel 1870-1878: 
Kuni 1870 aastani õli Koolmeistri ammet Jurri Strousti kääs. Jumal kutsus tedä oma targal tahtmisel igavise engusele. 1870 aastal Januari kuu algus sain mina (Paulus Paurmann) kooli ammeti oma hoolde. Siis antp Praost Meier mulle käso: Kooli óppetus peab saama uuve plaani järel antud, mitte ninda kui tänini sääl on ôld. 1878 aasta 23. Aprillini õpetasin mina Päite valla lapsi, ninda kuida mo nõder mõistus lubas.

Minu asemele sai Juri Sarap, tämä on kreis kooli hiilgavalt läbi tehnd, ja siis sellega täis praiguse aja koolmeister. - Tämä on ka üks täis rahvuslik mees. (H II 46, 71)

Kuivõrd Päite koolis õpetajaks olemine oli Paurmanni varasema elu kõige kauem kestnud järk (teistes ametites pidas ta vastu aasta-kaks), leidis see töö ka eluloos mõnevõrra mainimist. Samas polnud seal esiplaanil mitte õpetuse sisuline plaan, vaid enim tähelepanu said kohalikud intriigid, mille tagajärjel ta oma tööst loobuma pidi (H II 46, 217/9). Selles kultuuriloolises tekstis on ameti üleandmine esitatud tunduvalt neutraalsemas toonis. Siiski on oluline, et Paurmann ei öelnud ka oma eluloos uue õpetaja kohta midagi negatiivset, negatiivsena tajus ta seda viisi, kuidas teised kogukonna liikmed teda lahkumisotsust vastu võtma mõjutasid. ${ }^{6}$

Paurmanni omaelulooliste kirjutiste keskme moodustab tema elulugu, mida täiendavad mõningad eraldi esitatud seigad, mis üheltpoolt täiendavad eluloos olevat, teisalt võimaldavad teda ennast mõnevõrra erinevas raamistuses tutvustada. Eluloolise kihi eripäraks on selle suhteline hilisus - alles kolmandal kogumis-aastal otsustab ta sellega ühekorraga välja tulla. Ent vaatamata varasemale väitele, et elulugu tuleb siis, kui rahvaluule otsas (EKLA f $43, \mathrm{~m}$ 17: 17, 1 1/2), jätkab ta selle saatmise järel siiski kogumist.

Silbergleichiga võrreldes oli Paurmanni osalus kogumistöös mõnevõrra pikemaajalisem (üheksa saadetist nelja aasta jooksul), ning ta nägi ka enam vaeva, et saadetisi omavahel kokku siduda. Üheksast saadetisest kuuel on juures eksplitsiitne jätkamise lubadus, sealjuures kõige esimese saadetise lõpus olev märkus "Järg tuleb" (H II 8, 80) ongi kogu kaaskiri. Ning ka kõige viimase saadetise kaaskirjas on sees võrdlemisi tugev jätkamise lubadus: "Nõnda paljuks see kord vana varandust. Veel on kuulda kaugel vana kulla kolinat ja õbeda elinat. - Kui mahti ja parajat kuivamise aiga leian; siis kohe jälle võttan labidas pihku ja töö käsile.-" (H II 46, 138)

Miks see lubadus siiski täitmata jäi? Paurmanni kõige viimane saadetis jõudis Hurdani 1893. aasta mais. Samal või järgneval aastal suleti Lilienbachi kool, ning Paurmann suundus tagasi Päitesse talupidajaks, kuivõrd talu oli sama kehv kui ennegi, oli ots-otsaga kokku tulemine võrdlemisi keeruline (vt 
RMK II 204, 71). Seega - ehkki täpne naasmisaeg pole teada, kattub rahvaluulekogumise lõpp laias laastus kooliõpetaja karjääri lõpuga. Nii nagu Lilienbachi asumine andis talle aega ja võimalust tegeleda rahvaluulekogumisega, nii kadusid selleks tegevuseks vajalik aeg ja võimalused pärast lisatöökohast ilma jäämist.

\section{Paulus Paurmann ja Juhan Silbergleich: võrdluskohad}

Nii Silbergleichi kui ka Paurmanni saadetistes on märkimisväärne omaelulooline kihistus. Võimalik, et see elulooline kihistus on olnud inspireeritud Hurda vastavateemalisest palvest. Kumbki neist Hurda palvele küll ei viita, kuid Hurda mõju poolt võiks siiski kõneleda see, et nende eluloolised kirjutised pole pragmaatiliselt motiveeritud (s.t nende eesmärgiks ei ole oma tausta avamise kaudu mõjutada Hurta end aitama). Siiski saab Hurda küsimust tõesti käsitleda üksnes tõukeandjana, kuivõrd reaalsed tekstid on enamikust Hurdale laekunud vastustest selgelt erinevad. Mõlemad mehed soovisid omaelulooliste detailide kaudu edastada mingit üldisemat sõnumit, mis kummalgi juhul polnud päris kooskõlas rahvaluulekogumise kui sellise eesmärkidega. Sõnum omakorda oli seotud nende tehtud poeetiliste ja žanriliste valikutega.

Silbergleich kombineerib oma lähenemises kirjažanri ja ajakirjanduslikku tekstiloomet. Ta pöörab vähem tähelepanu narratiivi loogikale ning enam sellele, et esitatu oleks seotud kaasajaga, tuues esile mingeid kaasajale iseloomulikke probleeme. Silbergleichi kirjutiste keskmes on negatiivsed elukogemused, mille ta jutustamise kaudu asetab avaramasse raami, esitab neid metonüümilises suhtes suuremate kogukondade (olgu selleks siis väljarändajad või rahvustervik) kogemusega. Kirjapandus on väga vähe isiklikku (me ei saa midagi teada tema perekonna või hariduse kohta), esiplaanil on isiku avalik elu, suhted rahvuslike ettevõtmistega.

Paurmanni lähenemine on narratiivne, loo keskmes on tema ja ta pere, inimeste tunded ja omavahelised suhted. Ka tema kõneleb elus ettetulevatest pettumustest, kuid need pettumused ei ole üldistavad, vaid väga isiklikud ning pettumuste vahel on ruumi ka mõningatele positiivsetele seikadele. Väga isiklikult laetud narratiivi paigutab üldisemale taustale seos sentimentaalse kirjanduse võtetega ning ohter vanasõnade jm ütluste kasutamine sündmuste kommenteerimiseks - üks neist seob kirjutatu kirjakultuuri 'rahvaliku tasandiga', teine suulise kultuuriga.

Paistab silma, et poeetilised valikud, mida Silbergleich ja Paurmann omaeluloolisi tekste luues teevad, on selgelt seotud lugemisvaraga, mida nad Hurdale kirjutatus esile tõstavad. Silbergleich rõhutab oma varasemat ajalehtedele kaastöö tegemise kogemust ning tema enda elulooliste tekstide eesmärgiks 
näib olevat soov põhjendada teatud inimrühma valikuid (ja nende valikute paratamatust), rõhutada, et need inimesed ei vaja mitte põlgust, vaid kaastunnet. Paurmann aga toob esile sentimentaalset kirjandust ning ka tema omaelulooliste kirjutiste lähteks näib olevat soov mõtestada omaenda kogemusi läbi talle südamelähedase žanri. Samas on oluline, et nende enesepaigutus pole siiski päris ühene, vaid kummagi kirjutistes on marginaalsena kohal ka enese teistsugust positsioneerimist. See teistsugusus tuleb esile näiteks nende kultuuriloolistes tekstides. Just kirjutisse "Mõned orjapõlve riismed mite väga vanast ajast ..." (H II 33, 210/7) on Silbergleich põiminud ainsa perekonna ja isikliku eluga seotud mäluseiga, samas kui Paurmanni kirjutises "Tagasi vaate vana aika" (H II 46, 65/71) asendub eluloo perekeskne isik kultuuriloolise ja avalikuga.

Paurmanni ja Silbergleichi kui rahvaluulekogujaid ühendab see, et nad kuuluvad rahvaluulekogujate vanema põlvkonna hulka. See kajastub ühelt poolt vanuses - ajal, mil nad liitusid Hurda 1888. aastal alanud aktsiooniga oli Silbergleich 34- ning Paurmann 39aastane (enamasti olid kogujad alla 30aastased). Teisalt väljendub see ka asjaolus, et mõlemad tundsid rahvaluulekogumise vastu huvi juba enne Hurda 1888. aastal alanud aktsiooni. Silbergleich saatis üht-teist Mihkel Veskele (tõenäoliselt aastail 1882-1886, mil Veske oli Eesti Kirjameeste Seltsi esimees). Paurmann märgib, et esimesed rahvaluule kogumise katsetused (mida ta küll kusagile ei saatnud) tegi ta aastal 1878 (H II 37, 233), võimalik, et mõtte seda teha sai ta lugedes mõnd ajalehes ilmunud kogumistööle üleskutsuvat kirjutist ${ }^{7}$. Varasem huvi kogumistöö vastu muudab küsimuse kogumistööga liitumise motiividest nende kahe puhul keerukamaks. Kuna teame varasema kogumistöö kohta liialt vähe (ka pole säilinud kummagi mehe tolleaegseid üleskirjutusi ${ }^{8}$ ), on väga raske hinnata, kui sarnased olid kogumistööle ärgitavad olukorrad. Paurmanni puhul võib näha ühendava asjaoluna seda, et huvi kogumistöö vastu tärkas mõlemal juhul ajal, mil elukorraldus võimaldas lugemisaega. Silbergleich rõhutab mõlemal korral soovi osaleda rahvuslikes ühisettevõtmistes.

Samas ei saa kuidagi mööda sellest, et kahe erineva rahvaluulekogumisperioodi vahel on nende elus toimunud võrdlemisi suur muutus - mõlemast on saanud diasporaa-kogukonna liige. Mõlemal juhul oli sihtpunktiks nn lähivälismaa, s.o migratsiooniteekond oli suhteliselt lühike (võrreldes näiteks Siberi või Kaukaasiaga). Samas metafoorid, mida nad oma teekonna kirjeldamiseks kasutavad, loovad seosed tunduvalt pikemate rännetega - Silbergleich viitab juutide Paabeli vangipõlvele (vt eestpoolt), Paurmann võrdleb oma elu rändlindude omaga:

Mina igal suvel elan Päites, teen põllu tööd, sügisel kui linnud soojale maale lendavad, jättan ka mina oma südamest armastud abigasa ja 
lastega jumalaga, ja sõidan Vene maale, et seal midagi teenida, muidu eesti maal krundi peal elada ei või. (H II 37, 230)

Metafoore ühendab ka see, et mõlemad kannavad endas naasmise võimalust. Ühel juhul regulaarselt/hooajaliselt, teisel juhul kunagi tulevikus ja lõplikult; kuid oluline on just see, et praegune olukord ei jää kestma. Samas rõhutavad need metafoorid ka olukorra paratamatust - nii nagu juudid ei saa omatahtsi vangistusest naasta või rändlinnud otsustada kodumaale jääda, nii peavad nemadki oma aega ootama. Üldisemalt võib öelda, et need metafoorid haakuvad kenasti nende mõlema äärmiselt ambivalentse suhtega diasporaasse - ehkki nad rõhutavad väga teravalt toimunud piiriületust, näeme nende kirjutatus kohatist kodumaa ja diasporaa kokkusulamist, äravahetamist, nende-vahelise piiri hägustumist.

Silbergleich (kelle jaoks väljaränd ei osutunud õigeks valikuks) rõhutab igal võimalikul juhul oma diasporaa-positsiooni - lisaks juba eelpool väljatoodule on oluline tema kinnitus, et saadetud materjal põhineb tema oma mälul ning kirjade kirjapanemiskohaks on alati märgitud 'Jamburi kreisis, Sagooritsa mõisas'. Samas on põnev, et kõrvu diasporaa-olukorra erilisuse rõhutamisega toimub ta kirjutistes ka selle olukorra üldistamine rahvuskogukonnale - ühelt poolt võrdleb ta väljarändajaid Paabeli vangidega, teisal aga pillub üldistusi 'eestlane kannatab igal pool'. Tekib tunne, et piiriületus kui selline pole üldsegi oluline, eestlase jaoks on kõik igal pool üht-moodi (halvasti). Sama vastuolu tuleb esile ka fraasides "rasked elurõhumised juba kodumaalt peale hakates ..." (H II 33, 185) ning "suurem hulk raskeid elurõhumisi mis kodu isamajas aimata ei võinud siin alalise ja mitmesuguse pigistamise all kannatada saab!" (H II $33,209)$. Ta justkui ei suudaks otsustada, kas rõhutada tuleks diasporaa-olukorra erilisust või vastupidi olukorra muutumatust. Samas on võimalik, et see ambivalentsuse loomist kasutab ta võimalusena põhjendada oma diasporaasse edasijäämist, veenda iseennast selles, et kusagil mujal pole parem.

Erinevalt Silbergleichist Paurmann (kellel ajutine diasporaas viibimine aitas elu paremuse poole pöörata) pigem varjab oma suhteid diasporaaga. See väide võib näida mu eelneva arutluse taustal ehk vastuoluline - tõin ma ju esile, et tema eluloolistes kirjutistes oli Lilienbachi koolis tööle asumine oluliseks pöördepunktiks. Ent nii on see vaid siis, kui pöörame tähelepanu kirjapanekute omaeluloolisele kihile - väljaspool seda me mingeid viiteid Lilienbachi mõisale ei kohta - kõigi saadetiste ja enamiku kirjade (erandiks on EKLA f 43, m 17:17, 1 3/5) saatmiskohaks on märgitud Päite. Seda hoolimata sellest, et tema rahvaluulesaadetised on enamasti Hurdale ära saadetud aasta selles osas, mil ta oleks võinud viibida Lilienbachis. Kas viitab see sellele, et võrdlus rändlindudega oli vaid poeetiline metafoor ning tegelikult käis ta kodus sagedamini või hoopis soovile markeeringu 'Päite' kaudu äraoleku ajal korraks 'koju 
käia'? Ma pakun, et pigem oli põhjuseks see viimane - soov end ka äraoleku ajal kodukohaga seotuna tunda ${ }^{9}$.

Nii võib öelda, et nende mõlema jaoks oli kirjutamine üks võimalus kohaneda diasporaakogemusega, see aitas mõtteliselt siduda kodu ja uue asukoha. Ning ehk polegi ootamatu, et selleks kohanemiseks valisid nad kirjutusviisi, millega nad olid juba mõnevõrra varem kokku puutunud - rahvaluule kogumise. Ehkki selle valdkonna valiku võis loomulikult tingida ka soov just kaugel olles kodukoha eripärasid detailsemalt meelde tuletada ja läbi mõtestada, kirjutamise kaudu 'kodus käia'.

\section{Kokkuvõte}

19. sajandi lõpu rahvaluulekogujate poolt loodud rahvaluulekogudele saab läheneda mitmel moel - nii uurimaks (juba tol ajal) minevikku vajumas olevat pärimust kui ka selleks, et uurida kogude loomise aegset kultuuri ja eluolu, samuti seda, kuidas konkreetsed inimesed tajusid ühiskondlikke muutusi ning võtsid omaks uusi viise oma identiteedi määratlemiseks. Käesolevas artiklis heitsin pilgu kahe koguja omaeluloolistele tekstidele, s.o sellele, kuidas nad ühes konkreetses kirjutamiskontekstis kasutasid juhust omaenda kirjalikuks positsioneerimiseks. Lõpetuseks oleks aga ehk paslik asetada nende kogemus mõnevõrra avaramale ajastu-taustale.

Paurmann ja Silbergleich olid sama põlvkonna Virumaa mehed, kelle positsioon külaühiskonnas oli mõnevõrra ambivalentne. Ehkki nad tegelesid ka põllupidamisega, olid mõlemad seotud ka muude ametitega: Paurmann oli perekonna ootamatu vaesumise tõttu sunnitud vastu võtma erinevaid mittetraditsioonilisi tööotsi, ent ka Silbergleichi vallakirjutajaamet asetas ta tavapõllumehega võrreldes erilisele positsioonile. Ka osalemine rahvaluulekogumises oli kindlasti osa sellest ambivalentsusest - ehkki kogumine tähendab kohalike eripärade esiletoomist, tuleb impulss selleks alati väljastpoolt kogukonda. Tegevusse sukeldununa astub koguja omamoodi vahepealsele vahendajapositsioonile - ta ei ole enam päris kohalik, kuid ei kuulu veel ka haritlaste hulka.

Samas võib öelda, et ajastu üldplaani silmas pidades pole nende meeste lood ja kogemused üldsegi nii eripärased - teatav vahepealsus iseloomustas ju igaüht, kes kaasaegse kirjasõna vastu huvi tundis. Ka on oluline, et nende kirjutistes tulevad esile mitmed ajastule omased 'modernsed' märksõnad: rahvuslus, avalikkus ja mobiilsus. Leian, et nende külakogukonna ja haritlaste vahepealsele positsioonile kuuluvate kirjutajate tekstide kaudu on võimalik nende märksõnade (ning ühiskonna moderniseerumise) nüansseeritum/individuaalsem vaatlemine - esile tuleb see, kui erinevad võivad olla reaalsete inimeste suhted nende nähtustega. 
Rahvuslus. Sarnaselt enamiku teiste rahvaluulekogujatega jõudis info rahvaluulekogumise aktsioonide kohta nii Silbergleichi kui Paurmannini ajakirjanduse kaudu - mõlemad märgivad, et enne kogumistööga alustamist jälgisid nad kogumistöö kulgu aruannete vahendusel. Ajakirjandustekstides on kogumistöö olulisust enamasti põhjendatud viidetega rahvuslikkusele (isamaaline töö, kohus esivanemate ees jne) ning olen varasemalt viidanud, et väga paljudele kogujatele oli kogumistöö võimaluseks vähendada rahvuse mõiste abstraktsust (vt nt Kikas 2018). Silbergleich sobitub sellesse varasemasse tõdemusse võrdlemisi hästi - ta kuulub nende kogujate hulka, kes kasutavad rahvaluulekogumise raames võimalust rahvuse vastanduvaks mõtestamiseks, eestlaste madala positsiooni esiletoomiseks. Seevastu Paurmanni suhe rahvuslusse on tunduvalt ambivalentsem ja varjatum - ehkki tema märkus, et uus kooliõpetaja oli 'täis rahvuslik mees', oli ilmselgelt positiivne, ei aseta ta ennast kusagil sellesse identiteediraamistusse - ikka rõhutab ta oma perekonda ja lähemat ümbrust. Ma leian, et see on väga oluline viide sellele, et rahvuslikes ühisettevõtmistes osalevate inimeste arusaam rahvusest ning omaenda (või oma kogukonna) positsioonist selles võis olla väga erinev; nagu võib olla erinev seegi, kui eksplitsiitselt ning millises kontekstis seda identiteeditasandit rõhutatakse.

Avalikkus. Rahvaluulekogumise aktsioonides osalemine eeldas rohkem või vähem regulaarset meediatarbimist - ning tõesti nii Paurmann kui ka Silbergleich toovad esile oma ajalehelugemise harjumust. Ajakirjandusele kui levikukanalile toetumine muutis aga ka rahvaluulekogumise osaks avalikust kirjaruumist ning pakkus kogujatele võimalust osaleda selle kirjaruumi loomises, selle piiride katsetamises - viimases mõttes on põnev Silbergleichi viide tsensuurile. Silbergleichi ja Paurmanni omaeluloolised tekstid on ühelt poolt väga head näited sellest, kuidas kogujad kasutavad avalikust kirjaruumist pärit impulsse omaenda elu mõtestamiseks. Teisalt toob nende kõrvu asetamine esile selle kirjaruumi mitmetisuse, selle, et lisaks (rahvuslikult meelestatud) ajalehtedele loeti (ja nauditi) ka hoopis teistsuguseid kirjatöid. Sentimentaalse kirjanduse populaarsus lugejate seas pole ju üldsegi ootamatu (Vinkel 1966: 177-190), samas on selle esiletoomine Paurmanni poolt rahvaluulekogumise kontekstis siiski võrdlemisi eripärane - oli see ju miski, mida modernse kirjakultuuri seiskohast tajuti pigem marginaalse, liiga 'rahvalikuna'. Ehk siis: suhe rahvaluulekirjutajate tekstide ja kaasaegse kirjakultuuri vahel ei piirdunud vaid ajalehtede ja folklooritekstide väljaannetega, see oli tunduvalt avaram ja sügavam. Ning ehkki Paurmanni ja Silbergleichi (ja enamiku teiste rahvaluulekogujate) kirjapanekud ei osalenud reaalselt kaasaegse kirjakultuuri toimimises, annavad nad ometi olulise viite sellele, kuidas kaasajas lugemiseks saada olevaid tekste loeti, omavahel suhestati ning ise kirjatööd tegema asudes (taas)kasutati. 
Mobiilsus. Silbergleichi ja Paurmanni elulugude ühisosaks on väljarännukogemus. Ühel juhul oli ränne lõplik, teise puhul võib rääkida nn pendelrändest, kuid nii ehk teisiti on nad mõlemad kogujad, kelle hõlmamine üldnimetuse 'kohalik koguja' alla on olukorda liialt lihtsustav. Hurda ja Eiseni korrespondentide hulgas oli päris suur hulk neid, kes mingil põhjusel olid liikunud oma päritolukogukonnast ära (mõnda muusse kihelkonda, teistesse Vene impeeriumi piirkondadesse) - seega annavad 19. sajandi lõpu rahvaluulekogud kõige muuhulgas ka hea pildi inimeste mobiilsuse kasvust, ning sellega seotud paikkondliku identiteedi nihetest (vt nt Kikas 2018). Silbergleich ja Paurmann on ühelt poolt näited ebaõnnestunud ja õnnestunud rändevalikutest, teisalt on nad kindlasti väga head näited erinevatest võimalustest neid valikuid hiljem põhjendada, mõtestada ja üldistada. Diasporaa-kogemus on neile mõlemale ilmselgelt nii see, mis ärgitas neid kogumistööga liituma, kui ka see, mis andis tõuke iseendast kirjutada. Samas on just rändeteema see, mis nende meeste kogemuse ka tänapäeva seisukohalt nii aktuaalseks muudab.

\section{Kommentaarid}

1 Artikli valmimist on toetanud Euroopa Liit Euroopa Regionaalarengu Fondi kaudu (Eesti-uuringute Tippkeskus), see on seotud Eesti Haridus- ja Teadusministeeriumi uurimisprojektiga IUT 22-5 ja projektiga EKKM14-389.

2 Näiteks koguja A. Käärik viitab mitmel puhul oma taskuraamatule (E 15992, E 20323, H IV 8, 727/31). J. Lilienbach kirjutab aga täpsemalt: "Teie soovi katsun täita, nii pia kui napp aeg lubab. Palun kohe vabandust, kui see ehk pikemale viibib kui Teie ja ka ma ise sooviksime. Mustalt, ilma ümberkirjutamatta Teie kätte saatmine on võimata. Vana vara ei ole, kahjuks mull mitte järjest isepäinis ülesse tähendatud, vaid ta on minu muude kirjade vahel ja hulgas segamine. Ma kirjutasin nii, kuda mull misgi meele tuli, ehk kuda midagi kusgilt kuulsid. (Sellepärast oli mull alati paari poognaline raamat kää pärast - täis, jälle uus.) Sellepärast siis tuleb, et üks piatük on vana vara, teine uusvara, mõni sündind lugu oma tehtud laul vai jutt jne jne.” (E 1687).

3 Näiteks Hurda endise koguduseliikme Neerutist pärit Jüri Illaku kirjast (H II 31, $263 / 4,281 / 2$ ) on näha, et ka sellise suhte puhul pole isiklike teemade kirja lisamine iseenesest mõistetav. Rahvaluulekogumisega seotult omaeluloolisele viib lausekatke "Kui ma tohiks oma elu üle paar sõna ütelda, siis ..." (H II 31, 264), ning lõpus: "Et minu kiri vägise pikaks tükib minema, seda palun ma südamest andeks; sest Teil saab tuumakate kirjade lugemisegagi vist väega palju tegemist olema." (H II 31, 282).

4 Võimalik, et järgnev kirjeldus on pandud kirja vastusena Hurda elulugude-teemalisele palvele (ajaliselt klapiks Hurda 24. aruandega), samas puudub teksti juures viide Hurda palvele, ning puudu on mitmed detailid, mis enamasti ka kõige lakoonilisemalt kirjutatud tekstides olemas on (sünniaasta ja haridustee); seega ma seda kirjeldust Hurda palvega pigem ei seostaks (artiklis Kikas 2017a ma seda teksti allikate hulka pole kaasanud).

5 Sakalat on ta kindlasti lugenud aastatel 1878, 1881, 1882, aga võimalik, et mõni tellimiskiri on läinud kaduma (vt EKLA f 47, $\mathrm{m}$ 40: 24); teiste ajalehtede kohta kindlaid andmeid pole. 
${ }^{6}$ Siiski on huvitav, et ei siin ega tolles tekstis ei tule esile põhjus, mida kohaliku kooli ajaloo uurijad esile toovad - Päite kooli õpetus muutus venekeelseks, kuid Paurmann ei osanud seda keelt (Vallimäe 2011: 7). Koduloolase August Martini kirjutatud Paurmanni biograafias on õpetaja tööst loobumisele viidatud kui Paurmanni enda (mitte väga õnnestunud) otsusele, mingeid intriige ta välja ei too, ehkki ta on lugenud ka Paurmanni enda kirjutatud elulugu (vt RMK II 204, 96).

7 Aastatel 1872-1881 oli EKSi esimeheks Jakob Hurt, kes aastatel 1876-1878 avaldas ajalehtedes mitmeid vanavarakogumisega seotud kirjutisi (vt Saukas 2004: 169).

8 Paurmann ei saatnudki kirjapandut kuhugi; Veske Virumaa korjandus on läinud kaotsi (vt Saukas 2004: 175).

9 Nende valikute tulemusena on Silbergleich ka Hurda aruannetes markeeritud diasporaa kogujana, näiteks tänab Hurt teda teise korjanduse eest nii: "Sagoritsast, Jamburi maakonnast...Täname lahket saatjat ja rõõmustame, et väljarännanud suguvennad ka ikka osa võtavad." (Hurt 1889c). Paurmanni vastustes on aga alati "Päitest Jõhvi kihelkonnast" (vt nt Hurt 1889a).

\section{Arhiiviallikad}

\section{Eesti Kirjandusmuuseumis:}

EKLA - Eesti Kultuurilooline Arhiiv

H - Jakob Hurda rahvaluulekogu (1860-1906)

E - Matthias Johann Eiseni rahvaluulekogu (1880-1934)

RKM - Eesti TA Fr. R. Kreutzwaldi nim. (Riikliku) Kirjandusmuuseumi (nüüd Eesti Kirjandusmuuseumi) rahvaluule osakonna rahvaluulekogu

\section{Kirjandus}

Allan, David 2010. Commonplace books and reading in Georgian England. Cambridge: Cambridge University Press.

Barber, Karin 2006. Writing, genre and a schoolmaster's inventions in the Yoruba provinces. Barber, Karin (toim). Africa's Hidden Histories. Everyday Literacy and Making the Self. Bloomington and Indiapolis: Indiana University Press, lk 385-415.

Barber, Karin 2007. The Anthropology of Texts, Persons and Publics. Oral and written in Africa and beyond. Cambridge: Cambridge University Press.

Goršič, Ave 2017. The Life Behind Folklore Collecting: August Martin as a Correspondent of Folklore Archives. Bula, Dace \& Laime, Sandis (toim). Mapping the History of Folklore Studies: Centers, Borderlands and Shared Spaces. Cambridge Scholars Publishing, lk 73-84.

Hinrikus, Rutt 2016. Eesti autobiograafilise kirjutuse kujunemisest 18. sajandist II maailmasõjani. Hinrikus, Rutt. Kahe vahel. Artikleid kirjandusest ja elulugudest. Tartu: Eesti Kirjandusmuuseumi Teaduskirjastus, lk 200-221. 
Hurt, Jakob 1888. Neljas aruanne Eesti vanavara korjamisest ja keelemurrete uurimisest. 18. mail 1888. Olevik 23. V, lk 1; Postimees 21. V, lk 1.

Hurt, Jakob 1889a. Kolmaskümnes tõine aruanne Eesti vanavara korjamisest ja keelemurrete uurimisest. Aprillil 1889. Postimees 18. IV, lk 2, 22. IV, lk 1; Olevik 17. IV, lk 1.

Hurt, Jakob 1889b. Kaheskümnes tõine aruanne Eesti vanavara korjamisest ja keelemurrete uurimisest. Postimees 7. II, Olevik 30. I.

Hurt, Jakob 1889c. Kaheskümnes üheksas aruanne Eesti vanavara korjamisest ja keelemurrete uurimisest. 15. märtsi kuu päeval 1889. Postimees 30. III, lk 1; Olevik 20. III, lk 1 .

Hurt, Jakob 1890. Viieskümnes üheksas aruanne Eesti vanavara korjamisest ja keelemurrete uurimisest. 15, märtsil 1890. Postimees 28. IV, lk 3; Olevik 19. III, lk 3 (410).

Jansen, Ea 2004. Vaateid eesti rahvusluse sünniaegadesse. Tartu: Ilmamaa.

Jürgenson, Aivar 2015. Etniline ja rahvuslik. Etnokultuurilistest protsessidest eesti idadiasporaas. Acta Historica Tallinnensia 21, lk 23-50 (doi: 10.3176/hist.2015.1.02).

Jürjo, Indrek 2011. Ideed ja ühiskond. Balti provintside mõte- ja kultuuriloost 18.19. sajandil. Tartu: Eesti Ajalooarhiiv.

Kalkun, Andreas 2015. "Rohgem ei tiija mina teile kirjuda." Kirjavormelid ning peresuhete kajastused Jakob Ploomi sõjakirjades. Hinrikus, Mirjam \& Mattheus, Ave (toim). Esimene maailmasõda eesti kultuuris. Tallinna Ülikooli Eesti keele ja kultuuri instituudi toimetised 17. Tallinn: Tallinna Ülikool, Eesti TA Underi ja Tuglase Kirjanduskeskus, lk 116-144.

Kalmre, Eda 2010. Tüdrukute materjalikogudest ja eneseesitlusest internetis rate.ee päevikute armastusjutustuste näitel. Kalmre, Eda (koost). Tulnukad ja internetilapsed. Uurimusi laste- ja noortekultuurist. Tartu: EKM Teaduskirjastus, lk 215-245.

Kalmre, Eda 2017. About the Estonian Folklore Archives' album collection and perspectives on researching it. Goršič, Ave \& Järv, Risto \& Sarv, Mari (toim). Archives as Knowledge Hubs: Initiatives and Influences. Abstracts. Ave Tartu: ELM Scholarly Press, lk 26-27 (http://www.folklore.ee/era/conference2017/ERA90abstracts.pdf-11. mai 2018).

Kikas, Katre 2014. Folklore collecting as vernacular literacy: establishing a social position for writing in the 1890s Estonia. Edlund, Ann-Catrine \& Edlund, Lars-Erik \& Haugen, Susanne (toim). Vernacular literacies - Past, present and future. Northern Studies Monograps 3. Umeå: Umeå University, lk 221-235 (https://www.diva-portal. org/smash/get/diva2:736804/FULLTEXT02.pdf - 11. mai 2018).

Kikas, Katre 2017a. Rahvaluulekogujate elulood Jakob Hurda rahvaluulekogus. Keel ja Kirjandus 8-9, lk 584-599 (http://kjk.eki.ee/ee/issues/2017/8-9/958 - 11. mai 2018).

Kikas Katre 2017b. Rahvaluulekogumine epistolaarses kontekstis. Helene Maaseni kirjad Jakob Hurdale. Keel ja Kirjandus 4, lk 272-290 (keeljakirjandus.ee/download_ pdf/912 - 11. mai 2018).

Kikas, Katre 2018. Meenutatud keel ja unustatud kiri: rahvalikud keelekorraldajad J. Hurda rahvaluulekogus. Mäetagused. Hüperajakiri 70, lk 13-38 (doi: 10.7592/ MTG2018.70kikas). 
Korb, Anu 2017. Virumaa rahvaluule kogumine ja kogujad. Mäetagused. Hüperajakiri 66, lk 9-32 (doi: 10.7592/MT2017.66.korb).

Kurvet-Käosaar, Leena 2010. Mõtete rägastikus: autobiograafiast omaelulookirjutuseni. Methis. Studia humaniora Estonica. Omaelulookirjutus Eesti kultuuriloos 5-6, lk 7-19 (doi: 10.7592/methis.v4i5-6.514).

Laar, Mart 2001. Rahvas teeb raamatu, raamat teeb rahvuse. Tender, Tõnu (toim). Raamatu osa Eesti arengus. Eesti raamatu aasta avakonverentsi ettekanded Tartus 6.-7. aprillil 2000. Tartu: Ilmamaa, lk 11-17.

Nordlund, Taru 2013. Kirjeet. Keskustelua yli ajan ja paikan. Laitinen, Lea \& Mikkola, Kati (toim). Kynällä kyntäjät. Kansan kirjallistuminen 1800-luvun Suomessa. Helsinki: Suomalaisen Kirjallisuuden Seura, lk 107-138.

Saukas, Rein 2004. Mõistatuste kogumine Eesti Kirjameeste Seltsis aastatel 1872-1893. Mäetagused 26, lk 161-194 (doi: 10.7592/MT2004.26.saukas).

S[ilbergleich], J[uhan] 1878. Virumaalt. Virumaa tänavusest viljakasvust. Sakala 19. VIII, lk 2.

Valk, Ülo 2008. Saksad ja varavedajad: eesti muistendite sotsiaalsest orientatsioonist. Kalmre, Eda \& Västrik, Ergo-Hart (toim). Kes kõlbab, seda kõneldakse. Pühendusteos Mall Hiiemäele. Tartu: Eesti Kirjandusmuuseumi Teaduskirjastus, lk 57-73.

Vallimäe, Olav 2011. Päite kooli lugu. Toila valla lood V. Toila: Toila Valla Hariduse ja Kultuuri Selts.

Vinkel, Aarne 1966. Eesti rahvaraamat. Ülevaade XVIII ja XIX sajandi lugemisvarast. Tallinn: Eesti Raamat.

\title{
Summary
}

\section{Migratory bird and Babylonian prisoner: Life writing practices of Jakob Hurt's folklore correspondents}

\author{
Katre Kikas \\ Researcher, Department of Folkloristics, Estonian Literary Museum \\ katreki@folklore.ee
}

Keywords: collection of folklore, Juhan Silbergleich, life writing, Paulus Paurmann, 19th century

In the focus of this article are the life-writing practices of two Jakob Hurt's folklore correspondents. Jakob Hurt's folklore collecting campaign started in 1888 and about 1400 people stepped in to work along with him. Although collectors were aware of the scientific value of the work they were doing, there were many other reasons for them to be interested. Firstly, as collecting was considered as 'work for homeland', it was a possibility to assert one's national identity. Secondly, it offered a possibility to participate actively in the public written space; as the folklore collecting campaigns were organized 
with the help of newspapers, participants considered their work to be part of the public sphere (or at least closely connected to it). And thirdly, it was also quite a rare possibility to use one's writing skills in Estonian in a public setting; as the official languages at the time were German and Russian, the Estonian language was rather marginalized, yet at the same time the Estonian-language population's literacy rates were rather high.

Although folklore collecting may seem as a very restricted writing context, in reality collectors sent in widely varied sorts of texts - besides folklore texts there were letters, poems, life stories, interpretations of folklore, book reviews, texts resembling newspaper articles, and so on. Collectors really experimented with different genres and ways of addressing. In this article I have touched upon one layer in this textual field - writings in which collectors write explicitly about themselves and their lives, and where we can get a hint about how they wanted to be presented in this half-public space. The texts I have discussed are not autobiographies in the strict sense of the word; that is way I have used a more widely encompassing term - life writing.

Generally collectors do not write about themselves too often; yet, in some cases they do. Some of these texts are passages of letters addressed to the organizer of the campaign, with an aim to introduce oneself (e.g. in the first letter) or to convince the organizer to help the writer (e.g. in finding a new job). Some texts are embedded in the collections and presented as folklore, or added as a personal footnote to folklore material collected from others. Most of those personal texts have quite a self-downgrading frame - collectors apologize for including those 'irrelevant thoughts', therewith stressing the big gap between the social standing of the organizers (Hurt was a parson with a scientific degree) and themselves (mostly ordinary people with quite minimal schooling).

There are two male collectors in the centre of my article - Juhan Silbergleich (1854-?) and Paulus Paurmann (1850-1903). Both of them did quite extensive life writing in the contexts of their collecting activities, but the way they did it was rather different. Silbergleich starts writing about himself already in the first letter to Hurt; he never aims at something more coherent, all his life writing consist of bits and pieces embedded in letters and texts about cultural history. Paurmann keeps quite a humble profile for a couple of years and then sends in a long life story. Silbergleich's texts resemble newspaper articles and deal mostly with the poor living conditions of his community; he stresses his nationality quite often. Paurmann builds his life story on the model of sentimental literature, stressing his own deeds, feelings, and inner thoughts; he barely mentions the nation. One of the communal experiences of the men was life in diaspora community: they were born in Viru County, but in their later life moved to St. Petersburg Province (Silbergleich permanently, whereas Paurmann spent his winters there as a schoolteacher for Estonian-speaking children). This move plays quite an important role in their life writing. Yet, it was also an important incentive for the decision to start collecting folklore - for them it presented a possibility to be symbolically back home again.

In conclusion it can be said that, when reading the life writing texts of these two men side by side, we can see, on the one hand, two really different ways of putting one's life on paper (ways that are closely connected to the kind of reading material that those men preferred). Yet, on the other hand, we get quite a varied picture of some keywords (nationality, publics, mobility) of the time, linked with real lives of real people. 